\title{
THE AGGREGATE HARMONY METRIC AND A STATISTICAL AND VISUAL CONTEXTUALIZATION OF THE REHNQUIST COURT: 50 YEARS OF DATA
}

\author{
Peter A. Hook*
}

\section{INTRODUCTION}

An important anniversary went uncelebrated in the Harvard Law Review's most recent review of the previous United States Supreme Court term.' The November 2006 issue marked the fiftieth year that the Harvard Law Review published its annual matrix of the inter-agreement amongst all of the Justices for a particular term. ${ }^{2}$ These matrices include both raw numbers and

* Electronic Services Librarian. Indiana University School of Law-Bloomington: Doctoral Student, School of Library and Information Science (SLIS), Indiana UniversityBloomington. (JD University of Kansas 1997, MSLIS University of Illinois 2000). Mr. Hook researches in the area of information visualization. Particular interests include the educational use of knowledge domain visualizations, concept mapping, and the spatial navigation of bibliographic data in which the underlying structural organization of the domain is conveyed to the user. Additional interests include social network theory. knowledge organization systems, legal bibliometrics, and legal informatics. (The following website contains color versions of the visualizations used in this article: http://ella.slis.indiana.edu/ pahook/index.html.)

1. See The Supreme Court, 2005 Term, 120 HaRv. L. REV. 372, 372-84 (2006).

2. The Harvard Law Review first published the annual matrix in 1957 (regarding the $1956 \mathrm{Term})$. and has provided annual matrices ever since. See The Supreme Court, 1956 Term, 71 HARV. L. REV. 84, 103 (1957): The Supreme Court, 1957 Term, 72 HARV. L. REV. 96, 103 (1958); The Supreme Court, 1958 Term, 73 HARV. L. REV. 128, 133 (1959): The Supreme Court, 1959 Term. 74 HARV. L. REV. 95. 105 (1960); The Supreme Court, 1960 Term. 75 HARV. L. REV. 80, 89 (1961): The Supreme Court, 1961 Term, 76 HaRV. L. ReV. 75, 85 (1962): The Supreme Couri, 1962 Term, 77 HaRV. L. ReV. 79.87 (1963): The Supreme Courl, 1963 Term. 78 HARV. L. REV. 177. 183 (1964): The Supreme Court, 1964 Term, 79 HARV. L. REV. 103. 109 (1965); The Supreme Court, 1965 Term. 80) HaRV. L. REv. 123, 145 (1966): The Supreme Court, 1966 Term, 81 HARV. L. REv. 110. 131 (1967): The Supreme Court, 1967 Term, 82 HARV. L. REV. 93. 307 (1968): The Supreme Court, 1968 Term, 83 HARV. L. REV. 60. 279 (1969); The Supreme Court, 1969 Term, 84 HARV. L. REV. 30, 252 (1970): The Supreme Court, 1970 Term, 85 HARV. L. REV. 38, 351 (1971); The Supreme Court, 1971 Term, 86 HARV. L. REV. 50. 301 (1972): The Supreme Court, 1972 Term. 87 HARV. L. REV. 55, 304 (1973): The Supreme Court, 197.3 Term, 88 HARV. L. REV. 41, 275 (1974): The Supreme Court, 1974 Term. 89 HARV. 
percentages as to how often any two Justices sided together on cases for that particular term relative to the amount of cases the two Justices heard together. ${ }^{3}$ Aggregating this data over the fiftyyear span allows for some important insights and benchmarks as to the last half century of the Supreme Court - the 1956 to 2005 Terms. Given how often these or similar statistics are cited, ${ }^{4}$ emulated,' compiled and/or reproduced, the aggregated, longi-

L. REV. 47. 276 (1975): The Supreme Court, 1975 Term, 90 HARV. L. REV. 56, 277 (1976); The Suprente Court, 1976 Term, 91 HARV. L. REV. 70, 296 (1977); The Supreme Court, 1977 Term, 92 HaRv. L. REV. 57, 328 (1978); The Supreme Court, 1978 Term, 93 HARV. L. REV. 60. 276 (1979): The Supreme Court, 1979 Term, 94 HARV. L. REV. 75, 290 (1980): The Suprente Court, 1980) Term. 95 HARV. L. REV. 91. 340 (1981): The Supreme Court, 1981 Term, 96 HARV. L. REV. 62, 305 (1982); The Supreme Court, 1982 Term, 97 HARV. L. REV. 70. 296 (1983); The Supreme Court, 1983 Term, 98 HARV. L. REV. 87, 308 (1984); The Supreme Court, 1984 Term, 99 HARV. L. REV. 120.323 (1985): The Suprene Court, 1985 Term. 100 HaRV. L. REV. 100, 305 (1986); The Supreme Court, 1986 Term, 101 HaRV. L. Rev. 119. 363 (1987): The Supreme Courl, 1987 Term, 102 HaRv. L. Rev. 143. 351 (1988): The Suprente Court, 1988 Term, 103 HARV. L. REV. 137, 395 (1989); The Supreme Court, 1989 Term. 104 HARV. L. REV. 129. 360 (1990); The Supreme Court, 1990 Term, 105 Harv. L. Rev. 177, 420 (1991); The Supreme Courl, 1991 Term, 106 Harv. L. REV. 163, 379 (1992): The Supreme Court, 1992 Term. 107 HARV. L. REV. 144, 373 (1993); The Supreme Court, 1993 Tern, 108 HARV. L. REV. 139. 373 (1994): The Supreme Court, 1994 Term, 109 HaRV. L. REV. 111. 341 (1995): The Supreme Court, 1995 Term, 110 HARV. L. REv. 135. 368 (1996): The Supreme Court, 1996 Term, 111 HaRV. L. REV. 197. 432 (1997): The Supreme Court, 1997 Term, 112 HARV. L. REV. 122, 367 (1998); The Supreme Court, 1998 Term. 113 HaRV. L. REV. 400.401 (1999); The Supreme Court, 1999 Term-The Siatistics, 114 HaRV. L. REV. 179, 391 (2000): The Supreme Court, 2000 Term. 115 HaRV. L. REV. 539, 540 (2001); The Supreme Court, 2001 Term, 116 HaRV. L. REV. 453. 454 (2002): The Supreme Court, 2002 Term. 117 HARV. L. REV. 480, 481 (2003); The Supreme Court, 200.3 Term, 118 HARV. L. REV. 497, 499 (2004); The Supreme Court, 2004 Term, 119 HARV. L. REV. 415, 421 (2005); The Supreme Court, 2005 Term, 120 HARV. L. REV. 372,374 (2006). Hereinafter, each of the annual articles will be cited as follows: The (year/ Term. For example, the issue addressing the 2005 Term will be cited as The 2005 Term.

3. See supra note 2.

4. See, e.g. Paul Butler, Rehnquist, Racism, and Race Jurisprudence, 74 GEO. WASH. L. REV. 1019. 1030 (2006); Walter E. Joyce, The Early Constitutoinal Jurisprudence of Justice Stephen G. Breyer: A Study of the Justice's First Year on the United States Supreme Courl. 7 SETON HALL. CONST. L.J. 149. 161:Michael Stokes Paulsen, Counting Heads on RFRA. 14 CONST. COMMENT. 7, 12 (1997); Kevin H. Smith, Certiorari and the Supreme Court Agenda: An Empirical Analysis, 54 OKLA. L. REV. 727, 728 (2001): Stephen J. Wermiel. Clarence Thomas After Ten Years: Some Reflections, 10 AM. U.J. GENDER SOC. POL'Y \& L. 315, 316 (2002).

5. See Mark Tushnet, Taking Sides: Many Believe Political Differences Rend the Rehnquist Court. But More Than Politics Are in Play, LEgAL AffalRS, Mar.-Apr. 2005, at 38, available at http:/www.legalaffairs.org/issues/March-April-2005/numbers marapr(05.msp. At least one group of authors has repeatedly applied the Harvard Law Review's format and methodology to the voting patterns of the Indiana Supreme Court the Indiana Law Review has covered the voting patterns of the justices on the Indiana Supreme Court since its 1991 term. See, e.g., Mark J. Crandley et al., An Examination of the Indiana Supreme Court Docket, Dispositions, and Voting in 2005, 39 IND. L. REV. 733 (2006): Kevin W. Betz. An Examination of the Indiana Supreme Court Docket, Dispositions, and Voting in 1991, 25 IND. L. REV. 1469 (1992).

Others have done a similar analysis as to various state supreme courts. See Christine 
tudinal data should be of interest to scholars, commentators, law students, and the public at large.

Furthermore, these aggregated matrices of agreement allow for interesting visualizations of the Supreme Court, both longitudinally and year by year. Using existing software, measures of agreement (and disagreement) allow for the Justices to be distributed spatially as to their ideological sympathies. Such spatial visualizations quickly convey to the viewer which Justices are often in agreement, which are seldom in agreement, and which Justices are outliers. The fifty-year perspective also allows schol-

M. Motta, Note, The Supreme Court of Alaska: Unique and Independent Like the People of the Last Frontier, 60 ALB. L. REV. 1727, 1752 (1997); Stephen R. Barnett, Forward. The Emerging Court. 71 CAL. L. REV. 1134, 1193 (1983); Nathan J. Kunz et al., Note. Colorado Supreme Court Statistical Survey, 83 DENV. U. L. REV. 605 (2005); Shane R. Heskin. Note, Florida's State Constiutional Adjudication: A Significant Shift as Three New Members Take Seats on the State's Highest Court?, 62 ALB. L. REv. 1547 (1999): Robert Bradley \& S. Sidney Ulmer, An Examination of Voting Behavior in the Supreme Court of lllinois: 1971-7975, 5 S. ILL. U. L.J. 245 (1980); Annual Review of Maryland Law: Court of Appeals of Maryland, 1995.96 Opinions. 26 (1) U. BALT. L. REV. 1 (1996); Robert A. Marangola, Note, Independent State Constitutional Adjudication in Massachusetts: 1988-1998, 61 ALB. L. REV. 1625, 1675 (1998); Luke Bierman. The Dynamics of State Constitutional Decision-Making: Judicial Behavior at the New York Court of Appeals, 68 TEMP. L. REV. 1403 (1995); Vincent Martin Bonventre, Court of Appeals-State Constitutional Law Review, 1990, 12 PACE L. REv. 1 (1992) (discussing the New York Court of Appeals); Harry C. Martin. Statistical Compilation of the Opinions of the Stpreme Court of North Carolina Terms 1989-90 Through 1992-93, 72 N.C. L. REV. 1453 (1994); Michael West, Note, Arrested Development: An Analysis of the Oregon Supreme Court's Free Speech Jurisprudence in the Post-Linde Years, 63 ALB. L. REV. 1237 (200)(0): Glynna K. Parde, Note, Judicial Decision Making: A Statistical Analysis of the Tennessee Supreme Court-1992 Term, 24 MEM. ST. U. L. REV. 325 (1994); James E. Bond \& Kelly Kunsch, A State Supreme Court in Transition, 25 SEATTLE U. L. REV. 545 (2002) (discussing the Washington Supreme Court).

There is at least one study as to the voting alignment of a particular Federal Court of Appeals. Harry T. Edwards, Public Misperceptions Concerning the "Politics" of Judging: Dispelling Some Myths Abott the D.C. Circuit, 56 U. COLO. L. REv. 619, 644 (1985) (DC Circuit).

There is also at least one study on intermediate state appellate courts. See Rochelle Block \& Jeffrey Laynor, Note, The Work of the Court of Appeals: A Statistical Miscellany: July l, 1985 Through June 30, 1986, 46 MD. L. REV. 891, 898 (1987) (The star (*) footnote of this work cites several previous Maryland studies, including William L. Reynolds, II, The Court of Appeals of Maryland: Roles, Work and Performance-Part I, 37 MD. L. REV. 1, 40-56 (1977) (September 1975 Term) and others.).

6. See Paul H. Edelman \& Jim Chen, The Most Dangerous Justice Rides Again: Revisiting the Power Pageant of the Justices, 86 MINN. L. REV. 131. 190-191 (2001); Paul H. Edelman \& Jim Chen, The Most Dangerous Justice: The Supreme Court at the Bar of Mathematics, 70 S. CAL. L. REV. 63. 90 (1996): Brian K. Landsberg. Race and the Rehnquist Court. 66 TUL. L. REV. 1267, 1346-52 (1992); Linda Greenhouse. Court in Transition: News Analysis; Consistenly, A Pivotal Role. N.Y. TIMES. July 2, 2005, at A1 (including a chart titled, "Agreement Among Supreme Court Justices: Percentage of Times That Justices Agreed in Non-Unanimous Cases from the 1994-95 Term Through the 2003-04 Term"); Linda Greenhouse, Roberts Is at Court's Helm, But He Isn't Yet in Control, N.Y. Times, July 2, 2006, at 1 (including a chart titled. "Percentage of Times That Pairs of Justices Agreed in Nonunanimous Decisions in the 2005-06 Term"). 
ars of the court to set empirical benchmarks to evaluate individual terms. For instance, the 2005 term, with an aggregate agreement of $70 \%$, was the high water mark for agreement amongst the Court over the past 50 terms.' At least one scholar has described this as a "quiet term." Now, with the Aggregate Harmony Metric, we can empirically demonstrate that the term was unique. It was indeed a statistical outlier, a bit removed from the mean of $60 \%$ total Justice agreement for the fifty-year span.

\section{PRIOR WORK}

\section{A. Voting Alignments}

The genesis for voting alignment matrices appears" to be the work of C. Herman Pritchett in 1941." Pritchett's 1941 article contains a matrix of percentage agreement among the Justices in controversial cases during the 1939 and 1940 Terms." After a similar article in 1942 (which includes a table of the percentage agreement among the Justices in all non-unanimous cases for the 1941 Term (Chart III)), ${ }^{12}$ Pritchett produced a lengthier treatment of the subject in a 1948 book. ${ }^{13}$ Table XXII of this work consists of matrices of percentage agreements for all members of the Court for all non-unanimous opinions of the Court for the 1931 through 1946 Terms. ${ }^{14}$ A subsequent work by Pritchett contains matrices of percentage agreements for all members of the court for non-unanimous opinions of the Court for the 1946-1948 Terms (Table 5) ${ }^{15}$ and the 1949-1952 Terms (Table 7). ${ }^{16}$

In addition to the Harvard Law Review, others have published voting alignment and other data about the various terms

\footnotetext{
7. See infra Table 1 and Chart 1.

8. See Frederick Schauer. Forward. The Court's Agenda-and the Nation's. 120 HARV L. REV. 4, 32 (2006).

9. See J. Woodford Howard. Jr.. Commentary. 70 N.Y.U. L. REV. 533, 543 (1995).

10. C. Herman Pritchett, Divisions of Opinion Among Justices of the U.S. Supreme Court, 1939-1947. 35 AM. POL. SCI. REV. 890. (1941). For a discussion of Pritchett's work and other similar contributions, see Lee Epstein et al., The Political (Science) Context of Judging. 47 ST. LOLIS U. L.J. 783.786 (2003); G. Edward White, Unpacking the Iclea of the Judicial Center, 83 N.C. L. REv. 1089 (2005).

11. Pritchett. supra note 10. at 894 tbl. III.

12. C. Herman Pritchett. The Voting Behavior of the Supreme Court, 1941-42. $4 \mathrm{~J}$. POL. 491.497 tbl. III (1942).

13. C. Herman Pritchett. The Roosevelt Court: A Study in Judicial Politics and VALUES 1937-1947 (1948).

14. Id. at $24(0)-48$.

15. C. Herman Pritchett. Civil liberties and the Vinson Court 182 (1954).

16. Id. at 184 .
} 
of the Court. John Sprague published voting alignment data for as early as $1916 .^{17}$ At least as early as for the 1995 term, United States Law Week has published voting alignment matrices." In addition, The National Law Journal also publishes voting alignment data. ${ }^{19}$

Since the 1986 Term, a group of scholars has been publishing annual reviews of the Supreme Court with data such as liberal and conservative trends, voting for the government versus voting for private parties, breakdowns by civil and criminal cases, and other distinctions. ${ }^{211}$ Similar data is published in the wonderfully detailed book, The Supreme Court Compendium: Data, Decisions \& Developments. ${ }^{21}$ This work includes voting alignments by issue area: Criminal Procedure, Civil Rights, First Amendment, Due Process, Privacy, Attorneys, Unions, Economics, Judicial Power, Federalism, Interstate Relations, Federal Taxation, and Miscellaneous. ${ }^{22}$ The data for these tables comes from a freely available database known as the U.S. Supreme Court Judicial Database.

The U.S. Supreme Court Judicial Database was created by political scientist, Harold J. Spaeth, ${ }^{2+}$ and is widely used by the political science community. The database has been cited by law school scholars, and some note its discrepancies ${ }^{25}$ with the Har-

17. John D. Sprague. Voting Patterns of the United States Supreme COURT: CASES IN FEDERALISM. $1889-1959$ (1968).

18. Thomas C. Goldstein. Statistics for the Suprente Court's October Term 1995. 65 U.S.L.W. 3029 (1996).

19. Marcia Coyle, An Activist Court Rules on Speech, Immigration and One Big Election, NAT'L L.J., Aug. 6, 2001, at C1 (including table titled "Voting Alignments on the Supreme Court"); Marcia Coyle. New Trio Suands Up to Court's Hard Right, NaT'L L.J., Aug. 31, 1992, at S1 (including table titled "Voting Alignments on the Supreme Court: 1991-92 Term").

20. Robert E. Riggs, Supreme Court Voting Behavior: 1986 Term, 2 BYU J. PuB. L. 15 (1988); Richard G. Wilkins et al. Supreme Court Voting Behavior 2004 Term. 32 HASTINGS CONST. L. Q. 909 (2005).

21. Lee Epstein et al.. The Supreme Court Compendilim: Data, Decisions \& DEVElopMENTS (3d ed. 2003).

22. Id. at 524-87 (including tables for the Vinson Court. 1946-1952 Terms (Table 64): the Warren Court, 1953-1968 Terms (Table 6-5); the Burger Court. 1969-1985 Terms (Table 6-6); and the Rehnquist Court. 1986-2001 Terms (Table 6-7))

23. The S. Sidney Ulmer Project: U.S. Supreme Court Databases. http://www.as.uky.edu/polisci/ulmerproject/sctdata.htm

24. I $d$; ; see also JEFFREY A. SEGAL \& HARLOLD J. SPAETH. THE SUPREME COURT

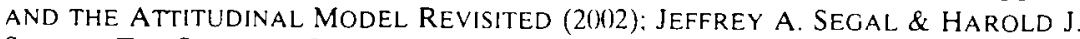
Spaeth, The Supreme Court and the Attitudinal Model 32.73 (1993): Harold J. Spaeth \& Jeffrey A. Segal, The U.S. Supreme Court Judicial Data Base: Providing New Insights into the Court, 83 JUDICATURE 228 (2000)

25. See Geraldine Mund, A Look Behind the Ruling: The Supreme Court and the Unconstitutionality of the Bankruptcy Act of 1978, 78 AM. BANKRUPTCY L.J, 401, 421 
vard Law Review statistics. In the future I plan to compare my results from the Harvard Law Review data against those from the Supreme Court Database. Some feel that the Supreme Court Database is more nuanced and transparent as to the processing and categorization of the data. ${ }^{26} 1$ personally found several minor errors and inconsistencies with the Harvard statistics ${ }^{27}$ and found myself wanting more information as to how the Harvard statistics were compiled. ${ }^{2 \pi}$

\section{B. Visualizations of Voting Alignments}

Over the years there have been several efforts to spatially visualize the relationship of the Justices to one another. ${ }^{2 y}$ In 1941, Pritchett published a linear continuum of the Justices in the 1939 and 1940 Terms based on their number of dissents. ${ }^{311}$ In 1951, Thurston and Degan used factorial analysis of the voting patterns of the 1943 and 1944 Terms to produce three dimensional vector space representations of the Justices. ${ }^{31}$ Starting in 1962, Schubert used multidimensional factor analysis (or scaling) of Justice voting behavior to produce spatial distributions of the

(2004):

26. See Epstein et al., supra note 10.

27. For example, the article concerning the 1967 Term uses the wrong $N$ value for Justice Marshall relative to Justice Black. The $\mathrm{N}$ value should be 70 instead of 170 to be consistent with the other $\mathrm{N}$ values for Justice Marshall and the resultant percentages in the five year table on p. 311 of the same volume. See The 1967 Term, supra note 2, at 307, 311. For the 1977 Term. the $P$ value should be 91.9 rather than 93.6. based on the $O, S, T$, \& N values given for Justice Marshall relative to Justice Brennan. See The 1977 Term, supra note 2, at 328 . For the 1985 Terms, there is a discrepancy as to the $\mathbf{N}$ value of Justice Powell relative to Justice White. It is 155 on one half of the matrix and 156 on the other half. The $1985 \mathrm{Term}$. supra note 2, at 305. I used the 155 value for my calculations as Justice Powell did not sit with any other Justice 156 times for that particular Term. However, he did sit with several other Justices a total of 155 times.

28. For example. Table $C$ and note $l$ in the section addressing the 1956 Term statistics indicate that there were thirty-three unanimous cases for the $1956 \mathrm{Term}$, "[i]ncluding 8 cases decided with concurring votes." The 1956 Term, supra note 2, at 103. Does this mean concurring in the judgment and the reasoning. or just the judgment? In the later case, only 25 are truly unanimous by later Harvart standards.

29. See G. Edward White, Unpacking the Idea of the Judicial Center, 83 N.C. L. REV. 1089 (2005) (discussing early statistical efforts that have produced spatial distributions of the Justices in order to find the spatial or ideological center of the Supreme Court)

30. Pritchett, supra note 8 , at 894 . For a more recent approach as to linear, spatial modeling taking into account more variables and in the context of the confirmation process see Jeffrey A. Segal et al.. A Spatial Model of Roll Call Voting: Senators, Constituents, Presidents, and Interest Groups in Supreme Court Confirmations, 36 AM. J. POL. SCI. 96 (1992)

31. L.L. Thurstone \& J.W. Degan, A Factorial Study of the Supreme Court, 37 PROC. OF THE NAT'L ACAD. OF SCI. OF THE U.S. 628 (1951). 
Justices. ${ }^{32}$ In 1985, Spaeth and Altfeld produced spatial, though non-automated, diagrams of the influence relationships amongst the Justices for the Warren and Burger Courts. ${ }^{33}$ More recently, Martin and Quinn used Markov chain Monte Carlo methods with a Bayesian measurement model to produce spatial distributions of Justices based on their voting behavior. ${ }^{3+}$

Other political scientists are using other statistical techniques based in part on voting behavior to produce spatial distributions of the Justices. ${ }^{35}$ Network science researchers Johnson, Borgatti, and Romney have used network science and correspondence analysis techniques to produce visual representations of the later Rehnquist Court voting patterns. ${ }^{36}$ Mathematician, Lawrence Sirovich, used vector models and singular value decomposition to produce two dimensional representations of the voting patterns of the Rehnquist Court. ${ }^{37}$ In addition, there have been numerous line charts showing various aspects of the work of the court. For instance, Epstein and her collaborators published a line chart showing the "Percentage of U.S. Supreme Court Cases with at Least One Dissenting Opinion, 1800-2000 Terms." ${ }^{3 \times}$

32. Giendon Schubert. Judicial Attiudes and Voting Behavior: The 1961Term of the United States Supreme Court, 28 LAW \& CONTEMP. ProBS. 100 (1963): Glendon Schubert, The 1960 Term of the Supreme Court: A Psychological Analysis, 56 AM. POL. SCl. REV. 90 (1962).

33. Harold J. Spaeth \& Michael F. Altfeld, Influence Relationships within the Supreme Court: A Comparison of the Warren and Burger Courts, 38 W. POL. Q. 70-83 (1985).

34. Andrew D. Martin \& Kevin M. Quinn. Dynamic Ideal Point Estimation via Markov Chain Monte Carlo for the U.S. Supreme Court, 1953-1999. 10 POL. ANALYSIS 134 (2002): see also Epstein et al. supra note 10. at 797: Andrew D. Martin et al.. The Median Justice on the United States Supreme Court, 83 N.C. L. REV. 1275 (2005): Lee Epstein et al., Ideological Drift Among Suprene Court Justices: Who When, and How Imporlant?. $102 \mathrm{Nw}$. U. L. REV. (forthcoming 2007), available at http:/www. law.northwestern.edu/lawrevicw/Colloquy/2007/8/LRColl2007n8Epstein.pdf.

35. See Lee Epstein et al., The Judicial Common Space (April 14. 2005) (research paper prepared for the Northwestern Faculty Conference, Law and Positive Political Theory: Legal Doctrine and Political Control. April 29, 2005), available at htlps://www.law.northwestern.edu/faculty/conferences/research/Epstein.pdt.

36. Jeffrey C. Johnson et al., Analysis of Voting Patterns in U.S. Supreme Court Decisions (February 16-20, 2005) (research paper prepared for Sunbelt XXV. International Sunbelt Social Network Conference. Redondo Beach, CA), abstract available at http://www.socsci.uci.edu/ ssnconf/conf/SunbeltXXVProgram.pdf.

37. Lawrence Sirovich. A pattern analysis of the second Rehnquist U.S. Suprente Courı, 100 PNAS 7432 (20)(3).

38. Epstein et al.. supra note 10, at 787. 


\section{Multidimensional SCAling (MDS) AND the LAw}

As this article utilizes Multidimensional Scaling (MDS), it is appropriate to survey the use of the technique by legal scholars generally, as well as those that have used it to produce spatial distributions of Supreme Court Justices based on their voting behavior. Most references in the law review literature are either by psychologists or health professionals, people citing psychologists or health professionals, people writing about psychological or health themes, or in law and psychology or law and health related journals. ${ }^{3 y}$ For instance, Blumenthal used multidimensional scaling to produce spatial distributions of various crimes based on the public's perception of the seriousness of the various crimes." Also, there is a group of scholars that has employed MDS to map social networks associated with various legal issues. These publications include spatial maps of the networks ${ }^{41}$ that are very similar to those produced in information science or social network science. Additionally, this author did a MDS analysis of top level West Topics in Supreme Court opinions over a sixty year span with the goal of creating a domain map of the Supreme Court topic space for teaching purposes. ${ }^{42}$

The use of MDS to produce visualizations of voting patterns in courts appears to have originated from its use to produce visualizations of Congressional roll-call votes. ${ }^{43}$ Grofman and Brazill have applied MDS to voting patterns of the Supreme Court. However, their focus has been to reduce the multidimen-

39. See Michael T. Heaney, Brokering Health Policy: Coalitions, Parties, and Interest Group Influence, 31 J. HEALTH POL., POL'Y \& L. 887 (2006); Maggie E. Reed et al.. There's No Place Like Home; Sexual Harassment of Low Income Womten in Housing. 11 PSYCHOL.. PUB. POL'Y, \& L. 439 (2005);

40. Jeremy A. Blumenthal, Perceptions of Crime: A Multidimensional Analysis with Implications for Law and Psychology, 38 MCGEORGE L. REV. (forthcoming 2007), available at http://ssin.com/abstract $=942311$

41. John P. Heinz et al., Lawyers for Conservative Causes: Clients, Ideology, and Social Distance, 37 L. \& SoC'Y REV. 5, 25, 31 (2003); John P. Heinz et al., The Constituencies of Elite Urban Lawyers, 31 LAW \& SOC'Y REV. 441, 444, 452. 458 (1997); John P. Heinz \& Peter M. Manikas, Networks Among Elites in a Local Criminal Justice System, 26 LAW \& SOC'Y REV. 831, 842, 847 (1992); Robert L. Nelson et al., Lawyers and the Structure of Influence in Washington, 22 LAW \& SOC'Y REV. 237, 289 (1988).

42. Peter A. Hook, Visualizing the Topic Space of the United States Supreme Court. (Indiana Legal Studies Research Paper No. 68), available at http://ssrn.com labstract $=948759$. Proceedings of the 11 th International Conference on Scientometrics and Informetrics (ISSI 2007), Madrid. Spain, June 25-27, pp. 387-96. working paper version (June 22. 2007).

43. See Keith T. Poole, Spatial Models of Parliamentary Voting (2005): Bernard Grofman \& Timothy J. Brazill. Itentifying the Median Justice on the Supreme Court Through Multidimensional Scaling: Analysis of "Natural Courts" 1953-1991. 112 Pub. Choice 55.55 n.1 (20()2). 
sional space to one dimension. In other words, they use MDS to produce a linear continuum of the Justices serving on any particular natural court (composed of nine Justices) to identify the central or median Justice. ${ }^{44}$ At least one scholar has produced two dimensional layouts of a particular Court term using MDS. ${ }^{45}$ However, the resultant visualizations are contained on a course website and appear to be more of a demonstration of the technique than an attempt to garner insight into the Supreme Court. $^{46}$

\section{NETWORK Visualizations and THE LAW}

Because this article uses network visualization techniques to visualize the relationship of the Justices based on their voting behavior, it is appropriate to survey the growing body of legal scholars doing similar work with legal networks. Smith, Cross and their collaborators utilize a dataset of the citation interlinkages of every federal and state case on Lexis as well as the citation interlinkages of 385,000 legal journal articles. ${ }^{47}$ Chandler utilizes the software program Mathematica to evaluate a dataset of the citation interlinkages amongst Supreme Court cases from 1831 to $2005 .^{\text {th }}$ Chandler has also written on the network structure of the Uniform Commercial Code. Political scientist Fowler and his collaborators also utilize the citation interlinkages for Supreme Court cases retrieved by automated means from Lexis to identify outwardly important cases and inwardly important cases." The CITE-IT Project analyzes the citation network of federal level regulatory takings cases. ${ }^{51}$

44. Grofman \& Brazill. supra note 43.

45. See Poli $100 \mathrm{~B}$ Congress, 2 February 2006, http://voteview.com/congress UCSD_2_February_2006.htm.

46. $I d$.

47. Frank B. Cross, Thomas A. Smith, \& Antonio Tomarchio, Determinants of Cohesion in the Suprene Court's Network of Precedents (Aug. 2006) (U of Texas Law, Law and Econ Research Paper No. 90. San Diego Legal Studies Paper No. 07-67), available at http://ssrn.com/abstract=924110; Frank B. Cross \& Thomas A. Smith. The Reagan Revolution in the Network of Law (June 2006), available at http://ssrn.com/abstract=909217; Thomas A. Smith, The Web of Law (Spring 2005) (San Diego Legal Studies Research Paper No. 06-11), available at http://ssrn.com/abstract $=642863$.

48. Seth J. Chandler, The Network Siructure of Supreme Court Jurisprudence (June 10. 2005) (University of Houston Law Center No. 2005-W-0) ), available at http://ssrn.com/abstract $=742065$.

49. Seth J. Chandler. The Network Structure of the Uniform Commercial Code: It's A Small World After All (2005) (paper presented at the 2005 Wolfram Technology Conference). available at http://Iibrary.wolfram.com/infocenter/Conferences $/ 5800 /$.

50. James H. Fowler et al.. Network Analysis and the Law: Measuring the Legal Importance of Supreme Court Precedtents, 15 POL. ANALYSIS 324 (2007); James H. Fowler. Connecting the Congress: A Study of Cosponsorship Networks. 14 POL. ANALYSIS 456 


\section{METHODOLOGY}

\section{A. Data Harvesting and Matrix Algebra}

The data for this article comes mostly from the Harvard Law Review's annual statistical review of the Supreme Court term. ${ }^{52}$ The author placed each year's data into a standardized spreadsheet matrix that had columns and rows for each Justice that participated in an issued opinion during the applicable time span - the 1956 to 2005 Terms (roughly October 1956 to July 2006). ${ }^{5.3}$ The author created one such spreadsheet per term for each of the different Harvard Law Review counting methods $\left(\mathrm{O},{ }^{54} \mathrm{~S},{ }^{55} \mathrm{D},{ }^{56} \mathrm{~N}^{57}\right)^{58}$. Relying on a consistent ordering of the Jus-

(2006): James H. Fowler \& Sangick Jeon. The Authority of Supreme Court Precedent. SOC. NETWORKS (forthcoming 2007), available at http://jhfowler.ucsd.edu/. .

51. Wayne McIntosh et al. Using Information Technology to Examine the Communication of Precedent: Initial Findings and Lessons From the CITE-IT Project (Mar. 17-19, 2005) (paper prepared for the 2005 Annual Meeting of the Western Political Science Association. Oakland, California). available at http:/www.bsos.umd. edu/gvpt/CITE-IT/Documents/McIntosh\%20etal\%202005\%20WPSA.pdf.

52. See supra note 2.

53. Sec infra Table 2 .

54. The O method counts the number of agreements in "opinions of the Court (O)" as indicated by the cell corresponding with any two Justices for that particular term. The 1956 Tern, supra note 2, at 103 tbl. IV. n.k. Subsequent issues would define the method as follows: " $O$ ' represents the number of decisions in which a particular pair of Justices agreed in an opinion of the Court or an opinion announcing the judgment of the Court." The 2005 Terni, supra note 2 , at 376 tbl. I. n.g.

55. The $\mathrm{S}$ method counts the number agreements in "separate opinions including concurrences and dissents" as indicated by the cell corresponding with any two Justices for that particular term. The 1956 Term, supra note 2, at $103 \mathrm{tbl}$. IV, n.k. Subsequent issues would define the method as follows: "S' represents the number of decisions in which two Justices agreed in any opinion separate from the opinion of the Court. Justices who together join more than one separate opinion in a case are considered to have agreed only once." The $20(0) 5$ Term. supra note 2 , at 376 tbl. I, n.g. The language as to Justices who "join more than one separate opinion in a case are considered to have agreed only once," did not come about until the 1996 Term. The 1996 Term, supra note 2, at 433 tbl. I, n.f. Thus. one would have to look at actual cases and voting patterns to see if the method was done consistently over the entire dataset.

56. The D method was introduced for the review of the 1987 term. " 'D' represents the number of decisions in which the two Justices agreed in either a majority, dissenting. or concurring opinion." The 1987 Ternt, supra note 2, at 252 tbl. I, n.f. It was in response to the problem of aggregated $O$ and $S$ totals leading to greater than 100 percent agreement. See id. " It should be noted that the 'P' totals have been computed differently than they have in past versions of this table. In the past, the ' $P$ ' line was calculated by dividing the sum of the ' $\mathrm{O}$ ' and ' $\mathrm{S}$ ' lines by ' $\mathrm{N}$.' This method of calculation overstated $\mathrm{P}$ whenever two Justices had agreed more than once in any one decision.")

57. The $\mathrm{N}$ method counts "the number of times that the Justices participated in the same case." The 1956 Term. supra note 2. at 103 tbl. IV. n.k. Subsequent definitions were very similar: " 'N' represents the number of decisions in which both Justices participated. and thus the number of opportunities for agreement." The 2005 Term, supra note 2. at 376 tbl. I, n.g.

58. The $\mathrm{T}$ method is merely the count of overall agreement. O plus $\mathrm{S}$. Because this 
tices, it was then easy to aggregate the data for each of the individual terms using Microsoft Excel. In other words, for each method type $(\mathrm{O}, \mathrm{S}, \mathrm{D}$, and $\mathrm{N})$, the author created one workbook file that had fifty individual sheets whose cell contents could easily be aggregated on the fifty-first sheet using the function: SUM(Sheet1:Sheet50!E3) where E3 was a particular cell. Thus, the Aggregate Harmony Metric is the aggregation of all $\mathrm{O}$ cells divided by the aggregation of all $\mathrm{N}$ cells $\left(\sum \mathrm{O} / \Sigma \mathrm{N}\right)$. These percentages were easily generated with a simple Excel function such as: Sheet1!D3/Sheet3!D3 where the cells in Sheet 1 contained all of the aggregated $\mathrm{O}$ values and the cells in Sheet 3 contained all of the aggregated $\mathrm{N}$ values."

\section{B. MDS (MULTIDIMENSIONAL SCALING)}

The visualizations that are Charts 4 and 5 were produced with the multidimensional scaling (MDS) algorithm embedded in the $\mathrm{R}$ statistical software package. ${ }^{\text {(f) }}$ The mathematics and principles behind MDS have been written about extensively ${ }^{\text {hl }}$ and will not be replicated here. Because the technique is based on the notion of distance, I subtracted the co-voting percentages from 100 to get distance integers - the larger the number, the greater the distance between Justices and vice-versa. Poole eloquently analogizes the MDS layout process to that of taking the mileage matrix of miles between cities found on many highway maps and creating a spatial distribution of the cities from that matrix. ${ }^{62}$ It is worth noting that with data that is not inherently spatial to begin with, there might be inherent stress in making everything fit. Also, a user can decide how many dimensions to which he or she wants to reduce the data with differing levels of stress. Because the first two dimensions capture the most variance in the data, these are what are represented in Charts 4 and 5.

The MDS algorithm is a deterministic process. This means that repeated processing of the data will produce similar spatial

could be derived automatically from the $\mathrm{O}$ and $\mathrm{S}$ matrices, the author did not input the data for this value by hand. The same is also true for the P Method. This is true whether "P" is derived by dividing " $T$ " by " $N$ " (T/N) as it was prior to the 1987 Term or by dividing "D" by "N" as it was for the 1987 Term and following.

59. See infra Table 2.

60. Free software is available at The $\mathrm{R}$ Project for Statistical Computing. http://www.r-project.org/.

61. See JOSEPH B. KRlskal \& Myron Wish. Mutlidimensional SCALing (1978): Blumenthal, supra note 4(): Grofman \& Brazill supra note 43.

62. POOLE. sapra note 43 , at 1 
distributions. (However, the image might be inverted up or down or left to right. It is as if the same two-dimensional slice through the solution space were viewed upside down or from the other side.) Stress tests reveal how well the variability of the data is captured by the chosen amount of dimensions. After conducting stress tests as to Supreme Court co-voting data, Grofman and Brazil were comfortable reducing all of the voting space to one dimension (a linear continuum) and note that a two-space solution "almost perfectly explain(ed) the data." ${ }^{63}$ This is fortunate as two-space, or two-dimensional, solutions are perfect for printed visualizations.

\section{NETWORK Visualizations}

To produce additional visualizations of the voting relationships on the Court ${ }^{\text {h4 }}$, I used the spring force layout algorithm embedded in the network analysis software Pajek. ${ }^{65}$ Network analysis is based on nodes and links. As to my data, the Supreme Court Justices became the nodes, and the links between them were a varying quantity corresponding to their percentage covoting agreement. The spring force layout algorithm used by the software is analogous to all the nodes being pulled together by rubber bands with the strength of the pull (and thus the proximity of the layout of the nodes) determined by the weight of the link. (Links are sometimes called edges and in this case are measure of co-voting percentages.) The layout algorithm is stochastic. This means that repeated processing of the data will produce different images. However, with complex node and link structures, the resultant images look more or less the same. (The orientation may be different and some nodes will be slightly different compared to each other.) However, the advantage of the network layout approach is that it can accommodate instances in which there are no ties between nodes as in the layout of all the

63. Grofman \& Brazill, supra note 43, at 58; set also Martin et al., supra note 34, at 1281 n.26 ("Nearly all statistical work on the United States Supreme Court suggests that the issue space is single-dimensional." (citing Grofman \& Brazill, supra note 43, at 58)).

64. See infra Charts 3, 7, and 8 .

65. Networks/Pajek: Program for Large Network Analysis, http://vlado.fmf.uni-lj. si/pub/networks/pajek/ (providing information and links to the Pajek software); see also WOUTER dE NOOY ET AL., EXPLORATORY SOCIAL NETWORK ANALYSIS WITH PAJEK (Structural Analysis in the Social Sciences Series No. 27, 2005); Vladimir Batagelj \& Andrej Mrvar, Pajek-Analysis and Visualization of Large Networks, in GRAPH DRAwING SOFTWARE 77 (Mathematics and Visualization Series, Michael Jünger \& Petra Mutzel eds., 2003); Vladimir Batagelj \& Andrej Mrvar, Pajek-Program for Large Network Analysis, 21(2) CONNECTIONS 47 (1998). 
Justices in the fifty-year dataset. ${ }^{\text {sh }}$ MDS, because it is based on distance, cannot handle such a structure in which there are entities that have no relationships. (A zero value corresponds to no distance and the two items are thought to be right on top of each other.)

\section{OBSERVATIONS, INSIGHTS AND FUTURE DIRECTIONS}

\section{A. Aggregate Harmony Metric}

The impetus for the Aggregate Harmony Metric is my desire to produce normalized spatial visualizations of the voting agreement per term for the entire fifty years of the dataset. In other words, I want to produce visualizations similar to Charts 4 and 5 for each Term of the Court and then combine them in an animation. However, it occurred to me that for the more rancorous, divisive terms that the Justices should be displayed further apart in the voting space. Similarly, for terms with high aggregate agreement, the Justices should be portrayed closer together. The Aggregate Harmony Metric functions as a simple means to make such an evaluation.

Table 1 provides the Aggregate Harmony Metric for each Term of the Court in the column labeled Aggregate Percentage Agreement (O Method). As can be seen from the line graph in Chart 1, the aggregate percentage agreement for the Court appears to seesaw through the fifty years of the dataset--from a low of $50 \%$ to a high of $70 \%$. The low value of $50 \%$ is for the 1970 Term. This was the outset of the change of direction from the more liberal Warren Court to the more conservative Burger Court. Justice Blackmun had just been appointed and was still voting solidly with his childhood friend, ${ }^{6}$ Chief Justice Burger (78\% voting agreement using the Harvard Law Review O Method $\left.{ }^{6 \times}\right) .{ }^{\text {(1) }}$ Indeed, a contemporaneous account observed that "the Warren Court momentum has been brought to a screeching halt" $"$ by the two new Nixon appointees Burger and Blackmun.

\footnotetext{
66. See infra Chart 3 .

67. LiNda GREENHOLSE, BECOMING JUSTICE BLACKMUN: HaRRY BLACKMUN'S SUPREME COURT JOURNEY (20)(15).

68. See The 1970) Term. supra note 2. at 351

69. This is in marked contrast to the voting agreement (O Method) for the last term the two served together (1985). which was $48 \%$. The 1985 Term. supra note 2 at 305 .

70. The 1970 Term, supra note 2. at 40 (citing Philip B. Kurland, The Burger Court Shows Its Stripes, 18 LAw SCH. REC. 7.9 (1971) (University of Chicago Law School)).
} 
At first glance, an Aggregate Harmony Metric of $50 \%$ seems implausible." As to the 1970 Term, however, of the 122 full opinions, less than $20 \%$ were unanimous $(23) .^{72}$ Furthermore, "there were fifteen major cases ... in which the Court was so split that the cases were decided without a majority opinion." ${ }^{, 73}$ This is in contrast to two such cases for each of the two previous terms. ${ }^{74}$ Additionally, seven cases were decided by a four to four vote and there were twenty cases decided by a four to five vote.

Contrast this to the 2005 Term in which $44 \%$ of the cases were unanimous ( 36 out of 81$)^{77}$ and there were only nine, five to four decisions. ${ }^{7 *}$ This "quiet" year had the highest Aggregate Harmony Metric $(70 \%)$ of the entire fifty-term span. This was most likely the result of several things: (1) O'Connor participating in twenty-four of the least controversial written opinions at the beginning of the term while Alito was going through the confirmation process; (2) the transition time after O'Connor's announced retirement and Rehnquist's death in which the Court might have been less likely to grant certiorari in controversial cases; and (3) efforts as to consensus building by the new Chief Justice Roberts. Table 3 displays the mean, median, mode, and various quartile distributions for all fifty of the Aggregate Harmony Metric values.

Table 4 reports the Aggregate Harmony Metric values for the tenure of each of the Chief Justices in the dataset. Consistent with the conventional understanding of the history of the Supreme Court, the Burger Court was a transitional time between the more liberal Warren Court and the more conservative Rehnquist Court. As might be expected, the Court of transition (the Burger Court) has a lower Aggregate Harmony value $(57 \%)$ than either the Warren Court $(59 \%)$ or the Rehnquist Court $(60 \%)$. Table 5 and Chart 2 tell a similar story at a finer scale of gradation (Five Term bins). One scholar has noted a

71. Assume that there were 100 cases for the term and all were decided by a five to four vote by the same block of Justices in the majority and in the dissent. This would yield an Aggregate Harmony Metric of $28 \%$ as the four dissenting Justices are not counted (using the $O$ Method) as having sided with either the 5 majority Justices or each of themselves. Thus. $\Sigma \mathrm{O}=1000$ and $\Sigma \mathrm{N}=3600$ ) and the Aggregate Harmon Metric $(\Sigma \mathrm{O} /$ $\Sigma \mathrm{N})=.2777$.

72. The 1970 Term. supra note 2. at 349.

73. Ill at 352 .

74. $/ \mathrm{ll}$.

75. Id. at 353

76. $l$ ld.

77. The 2005 Term, supra note 2. at 377.

78. Id. at 378 . 
change in the voting blocks of close decisions immediately after Bush v. Gore. ${ }^{7 /}$ One can look at the Aggregate Harmony Metric values to see that the 2000 Term (the year that the divisive opinion came out early in the Term) was itself higher than the median $(61 \%)$, that the 2001 Term took a dip below the median $(58 \%)$, that the 2002 Term was well above the median (63\%), and that the remaining Rehnquist Terms (2003 and 2004) were again at the median $(59 \%)$.

\section{B. VOTING SUPERLATIVES}

One benefit of having aggregated the Harvard Law Review's statistics for all fifty Terms (1956-2005) is the ability to see the highest and lowest voting agreement percentages between any two Justices over the span of the dataset. Tables $1,2,4,6,7$, 8 , and 9 and Chart 9 report various aspects of these voting superlatives. One can see that Warren and Marshall are at a fifty-year high for those having decided more than 100 cases together $(88 \%) .{ }^{\text {sil }}$ Indeed, Stephen Wermiel noted Marshall's proclivity to vote with Brennan in his analysis of the first ten years of Justice Thomas's tenure on the Court in regards to the assertion that Thomas was a "Scalia clone." In fact, the percentage of voting agreement between Scalia and Thomas for the time range of the dataset is $67 \%$. $^{{ }^{2} 2}$ This value is not even in the top twenty-five. ${ }^{{ }^{3.3}}$ Nor is it even in the forth quartile. ${ }^{\text {xt }}$ Similarly, the polemic nature of Justice Douglas is evident in the fact that he is one of the Justices in each of the first six, lowest voting agreement percentages.

There is utility in such measures. For one, the data might be of use to those scholars evaluating the "Freshman Effect." "

\footnotetext{
79. David Cole. The Liheral Legacy of Bush v. Gore. 94 GEO. L.J. 1427 (2006).

80. See infra Table 7.

81. See Wermiel. supra note 4 , at 316.

82. See infra Table 2.

83. See infra Table 7

84. See infra Table 10.

85. Sec infra Table 8.

86. See Terry Bowen \& John M. Scheb II. Reassessing the "Freshman Effect": The Voting Bloc Alignment of New Jastices on the United States Supreme Court. 1921-90, 15 POL. BEHAV. 1 (1993): Terry Bowen \& John M. Scheb. II. Freshman Opinion Writing on the U.S. Supreme Court, 1927-7991, 76 JUdICATURE 239 (1993): Saul Brenner, Another Look at Freshman Indecisiveness on the United States Supreme Court. 16 POLITY 320) (1983): Robert L. Dudley. The Freshman Effect and Voting Alignments: A Reexamination of Judicial Folklore. 21 AM. POL. RES. 360 (1993): Edward V. Heck \& Melinda Gann Hall. Bloc Voting and the Freshnan Iastice Revisited, 43 J. POL. 852 (1981); Christopher E. Smith. The Impact of New Justices: The U.S. Supreme Court and Criminal Justice. 30 AKRON L. REV. 55 (1996): see also David W. Allen, Voting Blocs and the Freshman. Ius-
} 
Also, it provides an empirical means of assigning labels. For instance, those in the fourth quartile might be considered ideological allies while those in the first quartile might be considered ideological opponents. Additionally, I plan to use the data to modify subsequent spatial layouts of the Justices based on their voting agreements. For instance, for those Justices whose voting agreements place them in the second and third quartiles, I plan to retain their actual distances as represented by the layout algorithm. However, I think it would be useful to double the distance of those in the first quartile and halve the distances for those in the forth quartile. ${ }^{x 7}$ This "distortion" would serve to heighten the relationships between Justices and reveal more strongly those that are ideologically close together and those that are ideologically far apart.

\section{Visualizations}

As an information science researcher, I am actively involved in the creation of knowledge domain visualizations (KDVs). KDVs are the "graphic rendering of bibliometric data designed to provide a global view of a particular domain, the structural details of a domain, the salient characteristics of a domain (its dynamics, most cited authors or papers, bursting concepts, etc.) or all three." ${ }^{\text {^ }}$ KDVs (also known as domain maps) respond to the desire of cognitive and educational psychologists to give learners "a big picture, a schema, a holistic cognitive structure[.]" Chart 3 provides such a big picture overview of the last fifty terms of the Supreme Court. There is an implied element of time moving from left to right. Viewers get a rough sense as to which Justices served with whom. Long serving Justices are pulled to the center of the diagram.

Additionally, it is my vision that Chart 3 will soon function as the navigational frontispiece of an online, informational website about the Court. By selecting two Justices, viewers would see their co-voting percentages as well as how these percentages compared to their contemporaries on the Court. Furthermore,

tice on State Supreme Courts. 44 W. POL. Q. 727 (1991).

87. See infra Table 10.

88. Peter A. Hook \& Katy Börner. Educational Knowledge Domain Visualizations: Tools to Navigate, Understand, and Internalize the Structure of Scholarly Knowledge and Experise, in NEW DIRECTIONS IN COGNITIVE INFORMATION RETRIEVAL 187. 194 (Amanda Spink \& Charles Cole eds., 20(05).

89. Charles K. West et al.. InSTRUCTIONAL DESIGN: IMPLiCATIONS fRom Cogvitive SCIENCE 58 (1991). 
users would be able to select a particular Term and only those Justices that served on the Court for that Term would be highlighted. The rest would be grayed out. Users could then navigate to MDS spatial distributions of the Justices for that particular Term and, aggregated with data from other recent terms, the spatial distributions for particular topics (free speech, federalism, criminal procedure, etc.)

Charts 4 and 5 are MDS produced spatial distributions of the co-voting percentages in non-unanimous cases of the longest serving group of the same nine Justices of the entire fifty-year dataset (1994 to 2003 Terms) - a large chunk of the Rehnquist Court. Chart 4, the aggregate co-voting figures for this time makes the ideological landscape of the court readily available to a novice. One can see that Scalia and Thomas are ideological allies far removed from the more liberal wing of the Court (Stevens, Ginsburg, Souter and Breyer). One can readily perceive that Stevens is the most marginalized Justice and most apt to go his own way. One can also see the most pronounced five to four voting block for this time (O'Connor, Kennedy, Rehnquist, Scalia and Thomas, versus Stevens, Ginsburg, Souter, and Breyer). ${ }^{* i}$

Chart 5 is the MDS produced spatial distribution of the covoting percentages in non-unanimous cases for the same time period (1994 to 2003 Terms) that the Harvard Law Review has identified in its Table of Contents for its annual review of the Court Term as dealing with Freedom of Speech and Expression." One can see that as compared to Chart 4, Stevens has moved from being marginalized to assuming the role of a centrist. Furthermore, Rehnquist, Scalia, and Thomas have themselves become marginalized and have moved away from each other. I do not pretend to be a constitutional scholar in the area of free speech. This calls attention to the issue that most visualizations should be validated by experts in the field to expose errors. For instance, maybe one or more of the cases identified as dealing with Freedom of Speech and Expression by the Harvard Law Review in its Table of Contents is only marginally so and significantly distorts the visualization.

90. See infra Chart 6

91. There are a total of twenty-five cases. which include. for example. Ashcroft $v$. ACLU, 542 U.S. 656 (2004): McConnell v. FEC. 540 U.S. 93 (2003): Virginia v. Black, 538 U.S. 343 (2003). (Virginia v. Hicks. 539 U.S. 113 (2003), was not included because it was a nine to zero decision.) 
Chart 6 emphasizes that O'Connor's change from one voting bloc to the next accounts for $63 \%$ of all five to four decisions (1994 to 2003 Terms). ${ }^{92}$ Thus, she is a quintessential swing vote. Furthermore, when Kennedy votes with the four liberal Justices this accounts for an additional $8 \%$ of all 5 to 4 decisions. ${ }^{4.3}$ The two of them together, covering just these three different voting bloc scenarios, account for $71 \%$ of all 5 to 4 decisions during the 1994 to 2003 Terms. ${ }^{34}$ The status of O'Connor and, to a lesser extent, Kennedy, as swing voters is visually portrayed in Charts 7 and 8 . In Chart 7, using the network graphic metaphor (nodes and edges), the lines between the Justices represent those voting together greater than $50 \%$ of the time in non-unanimous cases. This effectively communicates O'Connor's swing vote status between the liberal and conservative voting blocs for the time span. When the threshold is lowered by a mere percentage point as is the case in Chart 8, it can be seen that Kennedy also serves as an occasional swing vote between the liberal and conservative voting blocs. These visualizations effectively convey to a novice what almost every constitutional scholar or political scientist already knows. Just how effectively awaits rigorous user testing.

\section{CONCLUSION}

The Aggregate Harmony Metric is a tool to evaluate the relative rancorousness of the various terms of the Supreme Court. The insight from this metric is enhanced by knowledge of the all time high or low co-voting percentages between the Justices. Additionally, visualizations help to make the knowledge of veteran Court watchers quickly available and digestible to novices. All of this work responds to my desire to provide insights as to the Court for use in teaching (pedagogy). I think that metrics and visualizations can go a long way towards making the tacit knowledge of expert scholars of the Court available to both law students and the general public. Hard work, data mining, statistical data crunching, and visualization tools with built-in layout al-

92. O'Connor voted with Kennedy, Rehnquist. Scalia, and Thomas against Stevens. Breyer, Ginsburg. and Souter eighty-two times. O'Connor voted with Stevens, Breyer. Ginsburg. and Souter against Kennedy, Rehnquist. Scalia, and Thomas twenty-eight times. These totals. 82 plus $28(110)$, account for $63 \%$ of the 1755 to 4 votes for the time period. See the articles addressing the 1994 to 2003 Terms, supra note 2.

93. Kennedy voted eight times with Stevens, Breyer, Ginsburg, and Souter against O'Connor, Rehnquiest. Scalia. and Thomas. See the articles addressing the 1994 to 200$) 3$ Terms, supra note 2.

94. This is 124 of all of the 175.5 to 4 decisions. 
gorithms assist in making this possible. It is my hope that the field of information visualization as it relates to legal topics is still in its infancy and ripe for substantial growth.

Table 1A - Aggregate Harmony Metric ( $\Sigma O / \Sigma N)$

(1956-2005 Terms)

\begin{tabular}{|c|c|c|c|c|}
\hline Term & Court & $\begin{array}{l}\text { Aggregate Per- } \\
\text { centage Agreement } \\
\text { (O Method) }\end{array}$ & $\begin{array}{l}\text { Cumulative } \\
\text { O Count }\end{array}$ & $\begin{array}{l}\text { Cumulative } \\
\text { N Count }\end{array}$ \\
\hline 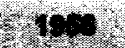 & Warren $3 \& 4$ & 57 & 2069 & 3631 \\
\hline 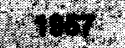 & Warren 4 & 66 & 2351 & 4188 \\
\hline $1+2$ & Warren 5 & 58 & 2206 & 3795 \\
\hline 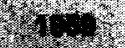 & Warren 5 & 51 & 1878 & 3651 \\
\hline $6 x$ & Warren 5 & 66 & 2257 & 4120 \\
\hline 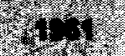 & Warren $5 \& 6$ & 62 & 1672 & 2681 \\
\hline 310 & Warren 7 & $\infty$ & 2245 & 3825 \\
\hline 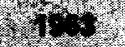 & Warren 7 & 67 & 2957 & 4440 \\
\hline 154 & Warren 7 & 6 & 1817 & 3146 \\
\hline (1.6\% & Warren 8 & 64 & 2095 & 3298 \\
\hline $1+3$ & Warren 8 & $\infty$ & 2412 & 4104 \\
\hline 434 & Warren 9 & 66 & 2624 & 4023 \\
\hline 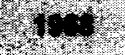 & Warren 9 & 62 & 2389 & 3835 \\
\hline 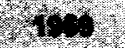 & Burger 1 & 62 & 1558 & 2509 \\
\hline 107 & Burger 2 & $\infty 0$ & 2118 & 4244 \\
\hline $17 n$ & Burger 3 & 84 & 2311 & 4279 \\
\hline 102 & Burger 3 & 66 & 3140 & 5666 \\
\hline 407 & Burger 3 & $B$ & 3079 & 5479 \\
\hline 1074 & Burger 3 & $\infty$ & 2779 & 4692 \\
\hline 10re & Burger $3 \& 4$ & 88 & 2905 & 5050 \\
\hline 1020 & Burger 4 & B5 & 2693 & 4890 \\
\hline ion & Burger 4 & 51 & 2279 & 4458 \\
\hline
\end{tabular}




$\begin{array}{lllll}\mathbf{1 9 7 8} & \text { Burger 4 } & \mathbf{5 6} & 2597 & 4707 \\ \mathbf{1 9 7 9} & \text { Burger 4 } & \mathbf{6 4} & 2801 & \mathbf{5 1 9 3} \\ \mathbf{1 9 8 0} & \text { Burger 4 } & \mathbf{5 4} & 2614 & 4805 \\ \mathbf{1 9 8 1} & \text { Burger 5 } & \mathbf{5 4} & 3187 & 5887 \\ \mathbf{1 9 8 2} & \text { Burger 5 } & \mathbf{5 6} & 3361 & 5792 \\ \mathbf{1 9 8 3} & \text { Burger 5 } & \mathbf{6 6} & 3689 & 5697 \\ \mathbf{1 9 8 4} & \text { Burger 5 } & \mathbf{6 6} & 3253 & 4965 \\ \mathbf{1 9 8 5} & \text { Burger 5 } & \mathbf{5 6} & 3136 & 5610 \\ \mathbf{1 9 8 6} & \text { Rehnquist 1 } & \mathbf{5 6} & 2998 & 5385 \\ \mathbf{1 9 8 7} & \text { Rehnquist 2 } & \mathbf{6 6} & 2904 & 4403 \\ \mathbf{1 9 8 8} & \text { Rehnquist 2 } & \mathbf{6 1} & 3087 & 5040 \\ \mathbf{1 9 8 9} & \text { Rehnquist 2 } & \mathbf{5 3} & 2633 & 4988 \\ \mathbf{1 9 9 0} & \text { Rehnquist 3 } & \mathbf{6 0} & 2505 & 4192 \\ \mathbf{1 9 9 1} & \text { Rehnquist 4 } & \mathbf{5 6} & 2119 & 3864 \\ \mathbf{1 9 9 2} & \text { Rehnquist 4 } & \mathbf{6 3} & 2566 & 4104 \\ \mathbf{1 9 9 3} & \text { Rehnquist 5 } & \mathbf{6 9} & 1830 & 3108 \\ \mathbf{1 9 9 4} & \text { Rehnquist 6 } & \mathbf{6 4} & 1947 & 3041 \\ \mathbf{1 9 9 5} & \text { Rehnquist 6 } & \mathbf{6 4} & 1813 & 2820 \\ \mathbf{1 9 9 8} & \text { Rehnquist 6 } & \mathbf{6 5} & 2002 & 3088 \\ \mathbf{1 9 9 7} & \text { Rehnquist 6 } & \mathbf{6 8} & 2261 & 3340 \\ \mathbf{1 9 9 8} & \text { Rehnquist 6 } & \mathbf{5 0} & 1703 & 2900 \\ \mathbf{1 9 9 9} & \text { Rehnquist 6 } & \mathbf{6 0} & 1652 & 2772 \\ \mathbf{2 0 0 0} & \text { Rehnquist 6 } & \mathbf{6 1} & 1859 & 3057 \\ \mathbf{2 0 0 1} & \text { Rehnquist 6 } & \mathbf{5 8} & 1665 & 2868 \\ \mathbf{2 0 0 2} & \text { Rehnquist 6 } & \mathbf{6 3} & 1765 & 2784 \\ \mathbf{2 0 0 3} & \text { Rehnquist 6 } & \mathbf{5 9} & 1682 & 2833 \\ \mathbf{2 0 0 4} & \text { Rehnquist 6 } & \mathbf{5 9} & 1629 & 2756 \\ \mathbf{2 0 0 5} & \text { Roberts 1 \& 2 } & \mathbf{7 0} & 1914 & 2749\end{array}$


Table 1B - Court Composition and Number of Full Opinions

(1956-2005 Terms)

Justices (When more than 9 justices are
involved in issuing opinions for a particular
term, those present for only part of the term
are denoted with the number of written cases
decided in which they participated. This
number is determined by the highest number
of cases in which two justices participated
(the Harvard N number) that includes the
particular justice sitting for only part of a
term.)

"Full

Opin-

ions"

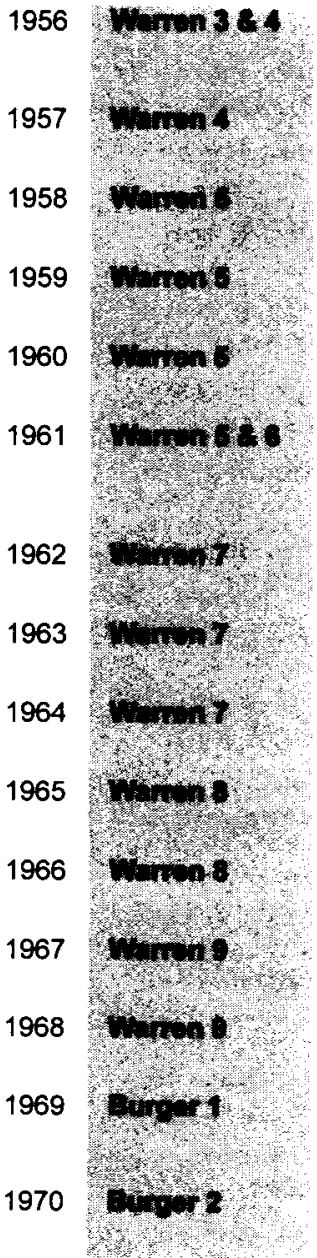

Black, Reed (42), Frankfurter, Douglas, Bur-

ton, Clark, Warren, Harlan, Brennan,

Whittaker (39)

Black, Frankfurter, Douglas, Burton, Clark,

Warren, Harlan, Brennan, Whittaker

Black, Frankfurter, Douglas, Clark, Warren, Harlan, Brennan, Whittaker, Stewart

Black, Frankfurter, Douglas, Clark, Warren, Harlan, Brennan, Whittaker, Stewart

Black, Frankfurter, Douglas, Clark, Warren, Harlan, Brennan, Whittaker, Stewart

Black, Frankfurter, Douglas, Clark, Warren, Harlan, Brennan, Whittaker (34), Stewart, White (16)

Black, Douglas, Clark, Warren, Harlan, Brennan, Stewart, White, Goldberg

Black, Douglas, Clark, Warren, Harlan, Brennan, Stewart, White, Goldberg

Black, Douglas, Clark, Warren, Harlan, Brennan, Stewart, White, Goldberg

Black, Douglas, Clark, Warren, Harlan, Brennan, Stewart, White, Fortas

Black, Douglas, Clark, Warren, Harlan, Brennan, Stewart, White, Fortas

Black, Douglas, Warren, Harlan, Brennan, Stewart, White, Fortas, Marshall

Black, Douglas, Warren, Harlan, Brennan, Stewart, White, Fortas, Marshall

Black, Douglas, Harlan, Brennan, Stewart, White, Marshall, Burger (8 JUSTICES

ONLY)

Black, Douglas, Harlan, Brennan, Stewart, White, Marshall, Burger, Blackmun 
1977 Buner

1978 Eurgor

1979 : Buroor 4

Douglas, Brennan, Stewart, White, Marshall, Burger, Blackmun, Powell, Rehnquist

Douglas, Brennan, Stewart, White, Marshall, Burger, Blackmun, Powell, Rehnquist

Douglas, Brennan, Stewart, White, Marshall, Burger, Blackmun, Powell, Rehnquist

Douglas, Brennan, Stewart, White, Marshall, Burger, Blackmun, Powell, Rehnquist

Douglas (5), Brennan, Stewart, White, Marshall, Burger, Blackmun, Powell, Rehnquist, Stevens (80)

Brennan, Stewart, White, Marshall, Burger, Blackmun, Powell, Rehnquist, Stevens

Brennan, Stewart, White, Marshall, Burger, Blackmun, Powell, Rehnquist, Stevens

Brennan, Stewart, White, Marshall, Burger, Blackmun, Powell, Rehnquist, Stevens

Brennan, Stewart, White, Marshall, Burger, Blackmun, Powell, Rehnquist, Stevens

Brennan, Stewart, White, Marshall, Burger, Blackmun, Powell, Rehnquist, Stevens

Brennan, White, Marshall, Burger, Blackmun, Powell, Rehnquist, Stevens, O'Connor

Brennan, White, Marshall, Burger, Blackmun, Powell, Rehnquist, Stevens, O'Connor

Brennan, White, Marshall, Burger, Blackmun, Powell, Rehnquist, Stevens, O'Connor

Brennan, White, Marshall, Burger, Blackmun, Powell, Rehnquist, Stevens, O'Connor

Brennan, White, Marshall, Burger, Blackmun, Powell, Rehnquist, Stevens, O'Connor

Brennan, White, Marshall, Blackmun, Powell, Rehnquist, Stevens, O'Connor, Scalia Rehnquist, Stevens, O'Connor, Scalia, Kennedy

, White, Marshall, Blackmun, Rehnquist, Stevens, O'Connor, Scalia, Kennedy

Brennan, White, Marshall, Blackmun, Rehnquist, Stevens, O'Connor, Scalia, Kennedy

White, Marshall, Blackmun, Rehnquist, Stevens, O'Connor, Scalia, Kennedy, Souter White, Blackmun, Rehnquist, Stevens, O'Connor, Scalia, Kennedy, Souter, Thomas White, Blackmun, Rehnquist, Stevens, O'Connor, Scalia, Kennedy, Souter, Thomas 
Blackmun, Rehnquist, Stevens, O'Connor, Scalia, Kennedy, Souter, Thomas, Ginsburg

Rehnquist, Stevens, O'Connor, Scalia, Kennedy, Souter, Thomas, Ginsburg, Breyer

Rehnquist, Stevens, O'Connor, Scalia, Kennedy, Souter, Thomas, Ginsburg, Breyer

Rehnquist, Stevens, O'Connor, Scalia, Kennedy, Souter, Thomas, Ginsburg, Breyer

1997

Orhoulats

Rehnquist, Stevens, O'Connor, Scalia, Kennedy, Souter, Thomas, Ginsburg, Breyer

1998

Pohmulets

Rehnquist, Stevens, O'Connor, Scalia, Kennedy, Souter, Thomas, Ginsburg, Breyer

1999

Rishquite 6

Rehnquist, Stevens, O'Connor, Scalia, Kennedy, Souter, Thomas, Ginsburg, Breyer

2000

Rehnqulet 6

Rehnquist, Stevens, O'Connor, Scalia, Kennedy, Souter, Thomas, Ginsburg, Breyer

2001

Rohnquits:

Rehnquist, Stevens, O'Connor, Scalia, Kennedy, Souter, Thomas, Ginsburg, Breyer

Rohnqulete

Rehnquist, Stevens, O'Connor, Scalia, Kennedy, Souter, Thomas, Ginsburg, Breyer

2003 Rehnquhats

Rehnquist, Stevens, O'Connor, Scalia, Kennedy, Souter, Thomas, Ginsburg, Breyer

2004 Pehnqubte 6

Rehnquist, Stevens, O'Connor, Scalia, Kennedy, Souter, Thomas, Ginsburg, Breyer

Stevens, O'Connor (24), Scalia, Kennedy, Souter, Thomas, Ginsburg, Breyer, Roberts, Alito $(40)$ 
Table 1C - Superlatives (Highest \& Lowest Percentage Agreement per Term (O Method) (1956-2005 Terms)

\begin{tabular}{|c|c|c|c|c|c|c|}
\hline Term & $\%$ & $\begin{array}{l}\text { Highest \% } \\
\text { Agree- } \\
\text { ment } \\
\text { Justice } 1\end{array}$ & $\begin{array}{l}\text { Highest } \\
\% \text { Agree- } \\
\text { ment } \\
\text { Justice } 2\end{array}$ & $\%$ & $\begin{array}{l}\text { Lowest } \% \\
\text { Agreement } \\
\text { Justice } 1\end{array}$ & $\begin{array}{c}\text { Lowest \% } \\
\text { Agree- } \\
\text { ment } \\
\text { Justice } 2\end{array}$ \\
\hline 1956 & 85 & Reed & Clark & 37 & Douglas & Harlan \\
\hline 1957 & 71 & $\begin{array}{l}\text { Black } \\
\text { Warren }\end{array}$ & $\begin{array}{l}\text { Warren } \\
\text { Brennan }\end{array}$ & 40 & Douglas & Harlan \\
\hline 1958 & 72 & $\begin{array}{l}\text { Clark } \\
\text { Whittaker }\end{array}$ & $\begin{array}{l}\text { Whittaker } \\
\text { Stewart }\end{array}$ & 38 & Douglas & Harlan \\
\hline 1959 & 78 & Warren & Brennan & 28 & Frankfurter & Douglas \\
\hline 1960 & 74 & Warren & Brennan & 34 & Frankfurter & Douglas \\
\hline 1961 & 9 & Clark & White & 37 & Black & Harlan \\
\hline 1962 & 83 & Warren & Brennan & 32 & Douglas & Harlan \\
\hline 1963 & 90 & Warren & Brennan & 42 & Black & Harlan \\
\hline 1964 & 89 & Warren & Brennan & 29 & Douglas & Harlan \\
\hline 1965 & 87 & Warren & Brennan & 36 & Douglas & Harlan \\
\hline 1966 & 86 & Warren & Brennan & 33 & Douglas & Harlan \\
\hline 1967 & 90 & Warren & Brennan & 46 & $\begin{array}{l}\text { Black } \\
\text { Douglas }\end{array}$ & $\begin{array}{l}\text { Harlan } \\
\text { Harlan }\end{array}$ \\
\hline 1968 & 92 & $\begin{array}{l}\text { Warren } \\
\text { Brennan }\end{array}$ & $\begin{array}{l}\text { Brennan } \\
\text { Marshall }\end{array}$ & 36 & Black & Harlan \\
\hline 1969 & 83 & Brennan & Marshall & 4 & Douglas & Burger \\
\hline 1970 & 78 & Burger & Blackmun & 36 & Douglas & Harlan \\
\hline 1971 & 6 & Stewart & White & 26 & Douglas & Rehnquist \\
\hline 1972 & 6 & Burger & Blackmun & 28 & Douglas & Rehnquist \\
\hline 1973 & $\pi$ & Burger & Rehnquist & 28 & Douglas & Rehnquist \\
\hline
\end{tabular}




\begin{tabular}{|c|c|c|c|c|c|c|}
\hline 1974 & 7 & Blackmun & Powell & 31 & Douglas & Rehnquist \\
\hline 1975 & 7 & Burger & Powell & 20 & Douglas & White \\
\hline 1976 & 68 & $\begin{array}{l}\text { White } \\
\text { Rehnquist }\end{array}$ & $\begin{array}{l}\text { Powell } \\
\text { Powell }\end{array}$ & 36 & Brennan & Burger \\
\hline 1977 & 62 & Brennan & Marshall & 32 & Brennan & Rehnquist \\
\hline 1978 & 70 & $\begin{array}{l}\text { White } \\
\text { Burger }\end{array}$ & $\begin{array}{l}\text { Blackmun } \\
\text { Powell }\end{array}$ & 34 & $\begin{array}{l}\text { Brennan } \\
\text { Marshall }\end{array}$ & $\begin{array}{l}\text { Rehnquist } \\
\text { Rehnquist }\end{array}$ \\
\hline 1979 & 6 & Burger & Powell & 30 & Marshall & Rehnquist \\
\hline 1981 & 6 & $\begin{array}{l}\text { White } \\
\text { Burger } \\
\text { Burger } \\
\text { Rehnquist }\end{array}$ & $\begin{array}{l}\text { Powell } \\
\text { Powell } \\
\text { Rehnquist } \\
\text { O'Connor }\end{array}$ & 35 & Marshall & Rehnquist \\
\hline 1982 & 7 & $\begin{array}{l}\text { White } \\
\text { Burger }\end{array}$ & $\begin{array}{l}\text { Burger } \\
\text { Powell }\end{array}$ & 37 & Marshall & Rehnquist \\
\hline 1983 & 8 & $\begin{array}{l}\text { White } \\
\text { Burger }\end{array}$ & $\begin{array}{l}\text { Burger } \\
\text { O'Connor }\end{array}$ & 45 & Marshall & Rehnquist \\
\hline 1984 & 81 & $\begin{array}{l}\text { Burger } \\
\text { Powell }\end{array}$ & $\begin{array}{l}\text { O'Connor } \\
\text { O'Connor }\end{array}$ & 47 & Marshall & Rehnquist \\
\hline 1985 & 81 & Powell & O'Connor & 37 & Marshall & Rehnquist \\
\hline 1986 & 77 & Rehnquist & Powell & 39 & $\begin{array}{l}\text { Marshall } \\
\text { Marshall }\end{array}$ & $\begin{array}{l}\text { Rehnquist } \\
\text { Scalia }\end{array}$ \\
\hline 1987 & 8 & White & Kennedy & 51 & Marshall & Scalia \\
\hline 1988 & 85 & Rehnquist & Kennedy & 47 & Marshall & O'Connor \\
\hline 1989 & 76 & White & Rehnquist & 35 & Marshall & Scalia \\
\hline 1990 & 8 & O'Connor & Souter & 39 & Stevens & Scalia \\
\hline 1991 & 72 & Kennedy & Souter & 32 & Blackmun & Scalia \\
\hline 1992 & 82 & Rehnquist & Kennedy & 44 & Stevens & Thomas \\
\hline 1993 & 72 & Rehnquist & O'Connor & 38 & Blackmun & Thomas \\
\hline 1994 & 8 & Rehnquist & Kennedy & 41 & Stevens & Thomas \\
\hline 1995 & 78 & O'Connor & Kennedy & 43 & Stevens & Thomas \\
\hline
\end{tabular}




\begin{tabular}{|c|c|c|c|c|c|c|}
\hline 1996 & 83 & Rehnquist & Kennedy & 44 & $\begin{array}{l}\text { Stevens } \\
\text { Stevens }\end{array}$ & $\begin{array}{l}\text { Scalia } \\
\text { Thomas }\end{array}$ \\
\hline 1997 & 86 & Rehnquist & Kennedy & 47 & Stevens & Scalia \\
\hline 1998 & 76 & $\begin{array}{l}\text { Rehnquist } \\
\text { O'Connor }\end{array}$ & $\begin{array}{l}\text { O'Connor } \\
\text { Kennedy }\end{array}$ & 37 & Stevens & Thomas \\
\hline 1999 & 86 & Rehnquist & O'Connor & 40 & Stevens & Scalia \\
\hline 2000 & 81 & Rehnquist & Kennedy & 40 & Stevens & Scalia \\
\hline 2001 & $\pi 7$ & Rehnquist & Kennedy & 37 & Souter & Thomas \\
\hline 2002 & 78 & Rehnquist & Kennedy & 44 & Stevens & Thomas \\
\hline 2003 & 78 & Rehnquist & O'Connor & 39 & Stevens & Scalia \\
\hline 2004 & 73 & O'Connor & Kennedy & 41 & $\begin{array}{l}\text { Stevens } \\
\text { Thomas }\end{array}$ & $\begin{array}{l}\text { Thomas } \\
\text { Ginsburg }\end{array}$ \\
\hline $200>->$ & 96 & O'Connor & Souter & 45 & Stevens & Alito \\
\hline
\end{tabular}




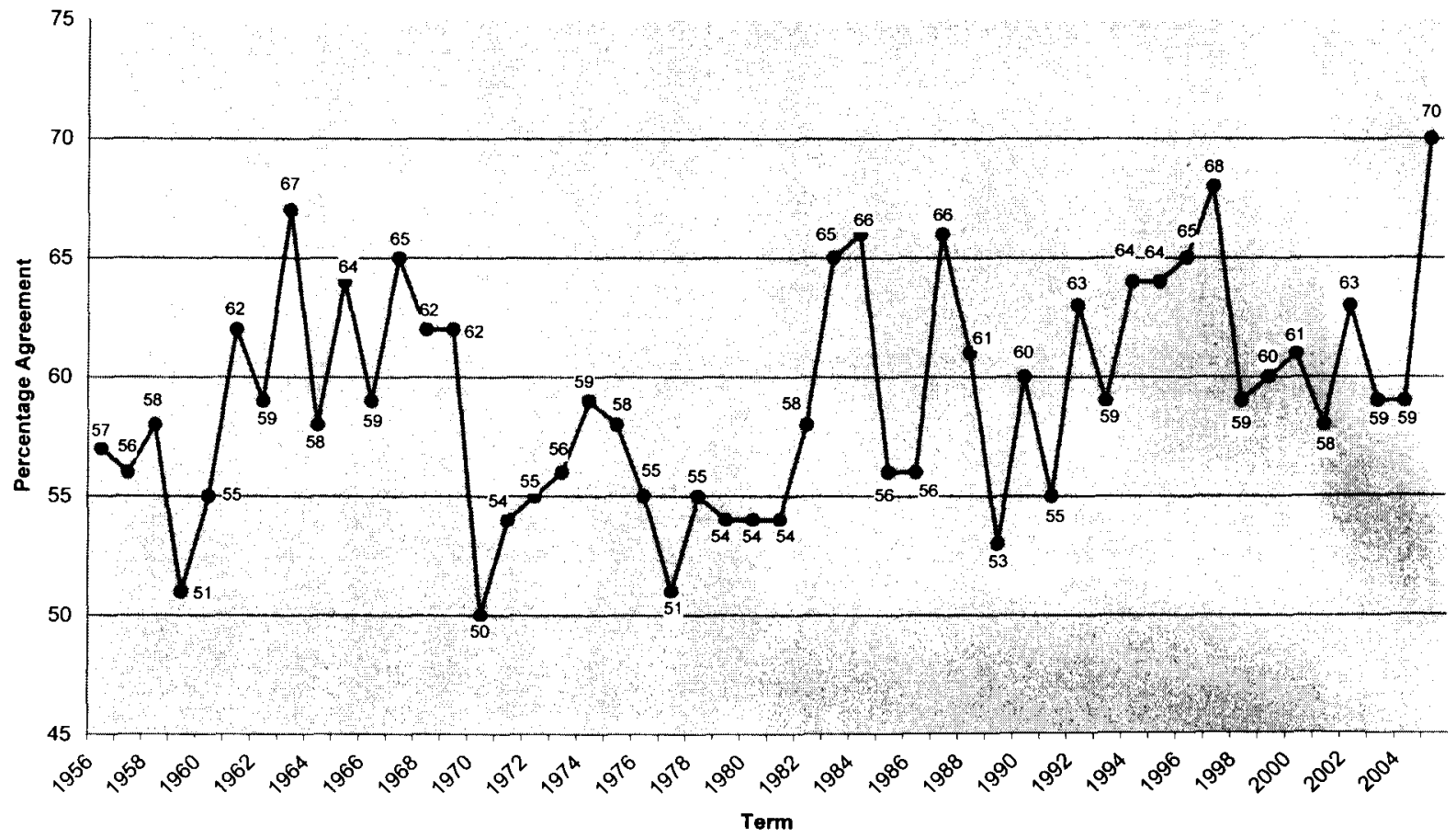


Chart 2-- Supreme Court Aggregate Agreement by Term (1956-2005)

5 Year Bins (Harvard Law Review O Method)

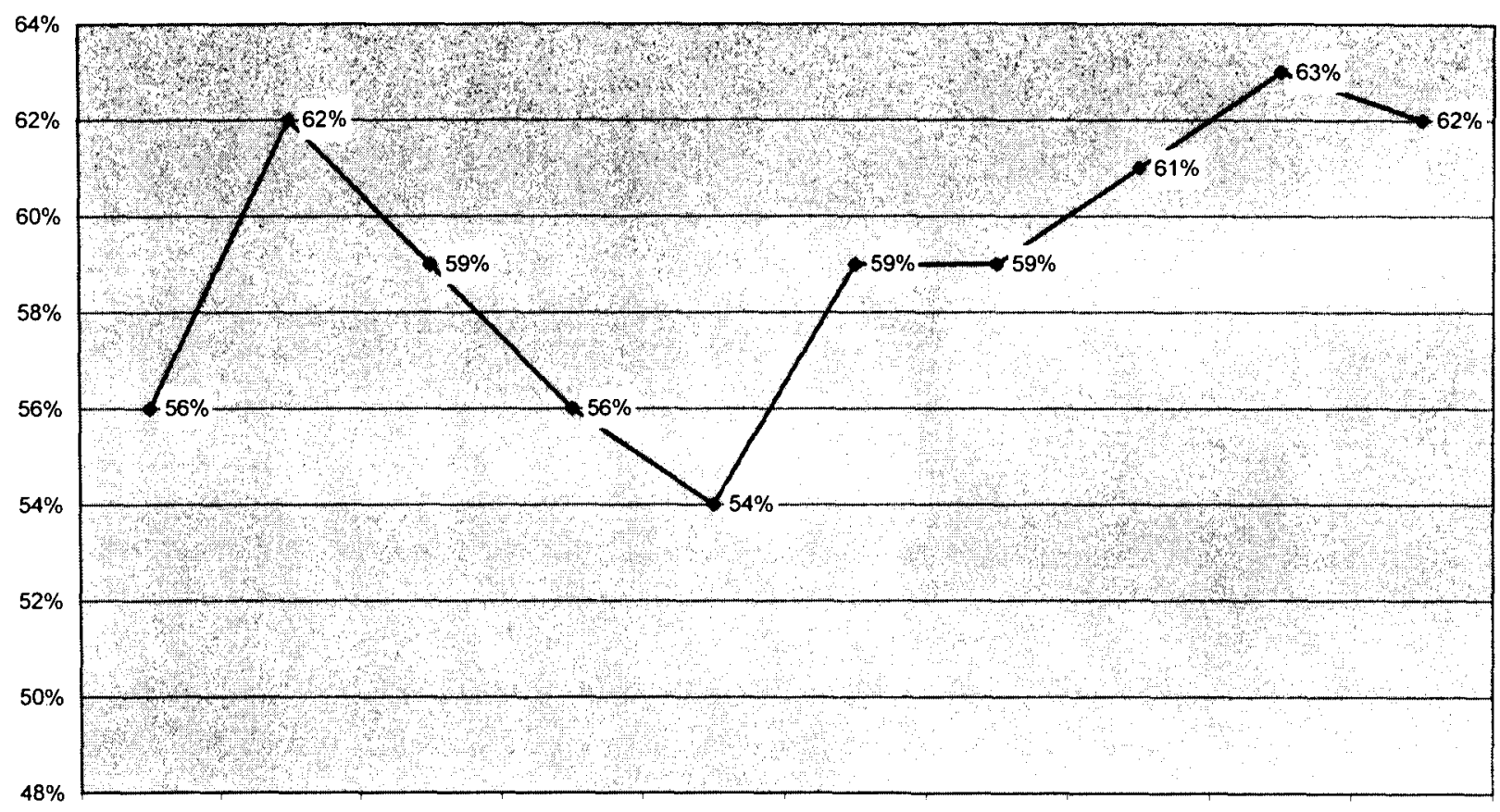

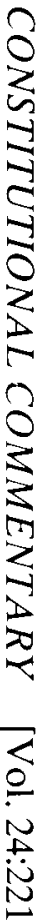

1956 to 19601961 to 19651966 to 19701971 to 19751976 to 19801981 to 19851986 to 19901991 to 19951996 to 20002001 to 2005 


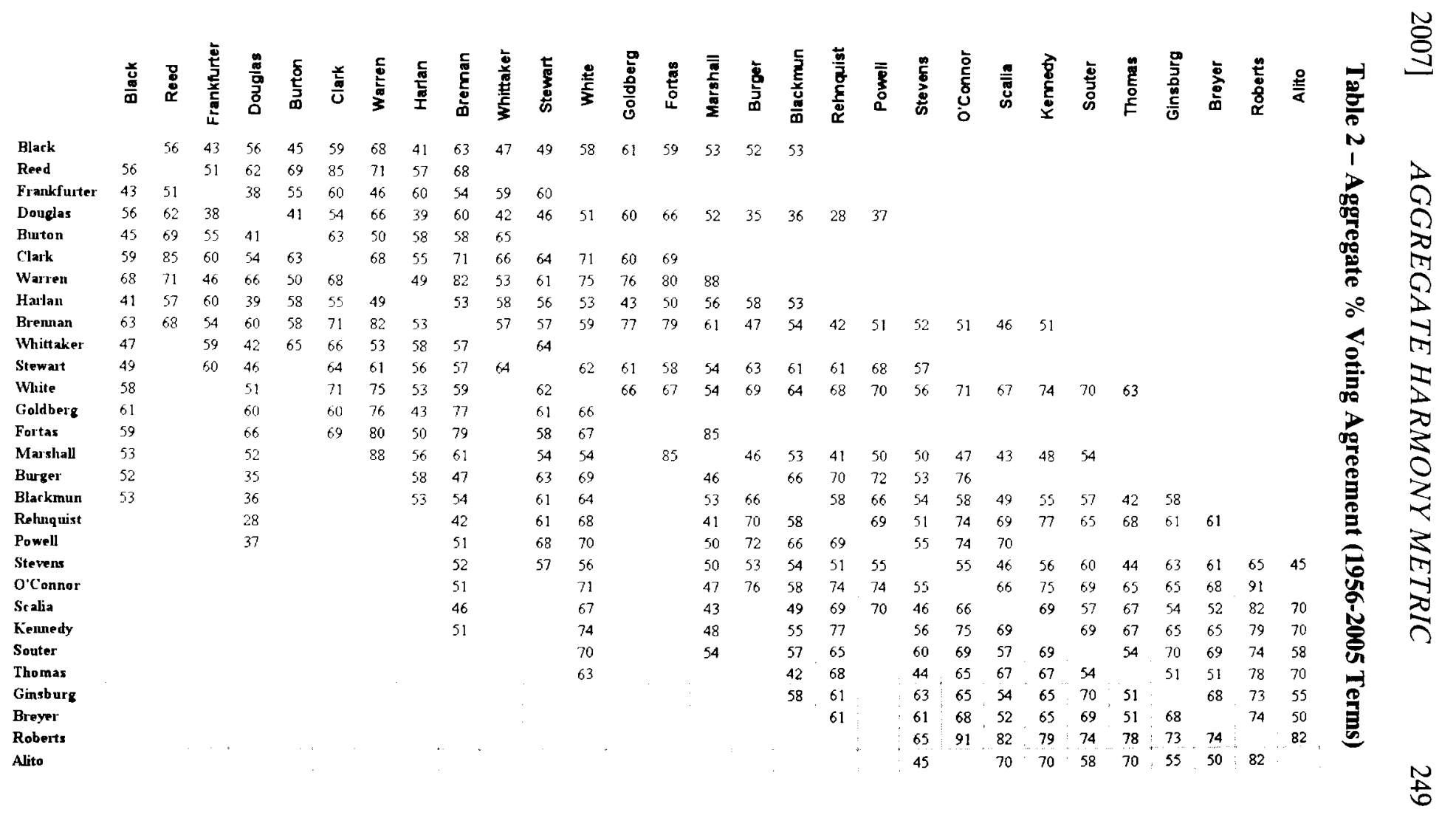


Table3: Statistics about the 50 Aggregate Harmony Metric Values (1956 - 2005 Terms)

(Calculated from $\mathrm{O} \& \mathrm{~N}$ data from the Harvard Law Review)

\begin{tabular}{|l|l|}
\hline Range of Aggregate Harmony Values & $50 \%$ to $70 \%$ \\
\hline Mean of Aggregate Harmony Values & $59.16 \%$ \\
\hline Median of Aggregate Harmony Values & $59 \%$ \\
\hline Mode of Aggregate Harmony Values & $59 \% \quad(70$ Occurrences) \\
\hline $1^{\text {st }}$ Quartile & $0 \%$ to $55.25 \%$ \\
\hline $2^{\text {nd }}$ Quartile & $55.26 \%$ to 59.16 \\
\hline $3^{\text {rd }}$ Quartile & $59.16 \%$ to $62.75 \%$ \\
\hline $4^{\text {th }}$ Quartile & $62.76 \%$ to $100 \%$ \\
\hline
\end{tabular}


Table 4 - Aggregate Co-Voting Statistics for the United States Supreme Court by Chief Justice Tenure (1956-2005 Terms)

\begin{tabular}{lcccc}
\multicolumn{1}{c}{ Court } & $\begin{array}{c}\text { Aggregate \% } \\
\text { Agreement } \\
\text { Method) }\end{array}$ & $\begin{array}{c}\text { Cumulative } \\
\text { O Count }\end{array}$ & $\begin{array}{c}\text { Cumulative } \\
\text { N Count }\end{array}$ & $\begin{array}{c}\text { "Full } \\
\text { Opin- } \\
\text { ions" }\end{array}$ \\
$\begin{array}{l}\text { Warren } \\
\text { (1956 to 1968) }\end{array}$ & 5 & 28,972 & 48,737 & $\mathbf{1 4 9 6}$ \\
$\begin{array}{l}\text { Burger } \\
\text { (1969 to 1985) }\end{array}$ & $\mathbf{5}$ & 47,500 & 83,923 & $\mathbf{2 4 0 8}$ \\
$\begin{array}{l}\text { Rehnquist } \\
\text { (1986 to 2004) }\end{array}$ & $\mathbf{6 0}$ & 40,620 & 67,343 & $\mathbf{1 9 1 3}$ \\
Roberts (2005) & $\mathbf{7 0}$ & 1914 & 2749 & $\mathbf{8 1}$
\end{tabular}

Table 4A - Aggregate Co-Voting Statistics for the United States Supreme Court by Chief Justice Tenure:

Superlatives (1956-2005 Terms)

\begin{tabular}{|c|c|c|c|c|c|c|}
\hline Court & $\%$ & $\begin{array}{l}\text { Highest \% } \\
\text { Agree- } \\
\text { ment } \\
\text { Justice } 1\end{array}$ & $\begin{array}{l}\text { Highest } \\
\% \text { Agree- } \\
\text { ment } \\
\text { Justice } 2\end{array}$ & $\%$ & $\begin{array}{c}\text { Lowest \% } \\
\text { Agreement } \\
\text { Justice } 1\end{array}$ & $\begin{array}{c}\text { Lowest \% } \\
\text { Agree- } \\
\text { ment } \\
\text { Justice } 2\end{array}$ \\
\hline $\begin{array}{l}\text { Warren } \\
\text { (1956 to } \\
1968)\end{array}$ & 90 & Brennan & Marshall & 38 & $\begin{array}{l}\text { Frankfurter } \\
\text { Douglas }\end{array}$ & $\begin{array}{l}\text { Douglas } \\
\text { Harlan }\end{array}$ \\
\hline $\begin{array}{l}\text { Burger } \\
\text { (1969 to } \\
1985)\end{array}$ & 76 & Burger & O'Connor & 28 & Douglas & Rehnquist \\
\hline $\begin{array}{l}\text { Rehnquist } \\
\text { (1986 to } \\
2004)\end{array}$ & 77 & $\begin{array}{l}\text { Rehnquist } \\
\text { Rehnquist }\end{array}$ & $\begin{array}{l}\text { Powell } \\
\text { Kennedy }\end{array}$ & 42 & Blackmun & Thomas \\
\hline $\begin{array}{l}\text { Roberts } \\
(2005)\end{array}$ & 96 & O'Connor & Souter & 46 & Stevens & Alito \\
\hline
\end{tabular}


Table 5 - Aggregate Co-Voting Statistics for the United States Supreme Court

5 Year Bins (1956-2005 Terms)

\begin{tabular}{|c|c|c|c|c|c|}
\hline Term & Court & $\begin{array}{l}\text { Aggre- } \\
\text { gate \% } \\
\text { Agree- } \\
\text { ment (O } \\
\text { Method) }\end{array}$ & $\begin{array}{c}\text { Cumulative } \\
\text { O Count }\end{array}$ & $\begin{array}{l}\text { Cumulative } \\
\text { N Count }\end{array}$ & $\begin{array}{c}\text { Average } \\
\text { Yearly No. } \\
\text { of "Full } \\
\text { Opinions" }\end{array}$ \\
\hline $\begin{array}{l}1956 \text { to } \\
1960\end{array}$ & Warren & 56 & 10,761 & 19,385 & 114 \\
\hline $\begin{array}{l}1961 \text { to } \\
1965\end{array}$ & Warren & 62. & 10,786 & 17,390 & 110 \\
\hline $\begin{array}{l}1966 \text { to } \\
1970\end{array}$ & $\begin{array}{l}\text { Warren / } \\
\text { Burger }\end{array}$ & 59 & 11,101 & 18,715 & 117 \\
\hline $\begin{array}{l}1971 \text { to } \\
1975\end{array}$ & Burger & 56 & 14,214 & 25,166 & 154 \\
\hline $\begin{array}{l}1976 \text { to } \\
1980\end{array}$ & Burger & 54 & 12,984 & 24,053 & 140 \\
\hline $\begin{array}{l}1981 \text { to } \\
1985\end{array}$ & Burger & 69 & 16,626 & 27,951 & 160 \\
\hline $\begin{array}{l}1986 \text { to } \\
1990\end{array}$ & Rehnquist & 69 & 14,127 & 24,008 & 139 \\
\hline $\begin{array}{l}1991 \text { to } \\
1995\end{array}$ & Rehnquist & 61 & 10,275 & 16,937 & 96 \\
\hline $\begin{array}{l}1996 \text { to } \\
2000\end{array}$ & Rehnquist & 63 & 9477 & 15,157 & 86 \\
\hline $\begin{array}{l}2001 \text { to } \\
2005\end{array}$ & $\begin{array}{l}\text { Rehnquist / } \\
\text { Roberts }\end{array}$ & 62 & 8655 & 13990 & 6 \\
\hline
\end{tabular}


Chart 3 - Justices of the U.S. Supreme Court (1956-2005 Terms) [Spatial distribution based on the percentage of co-voting in Supreme Court opinions. Rendered with Pajek.]

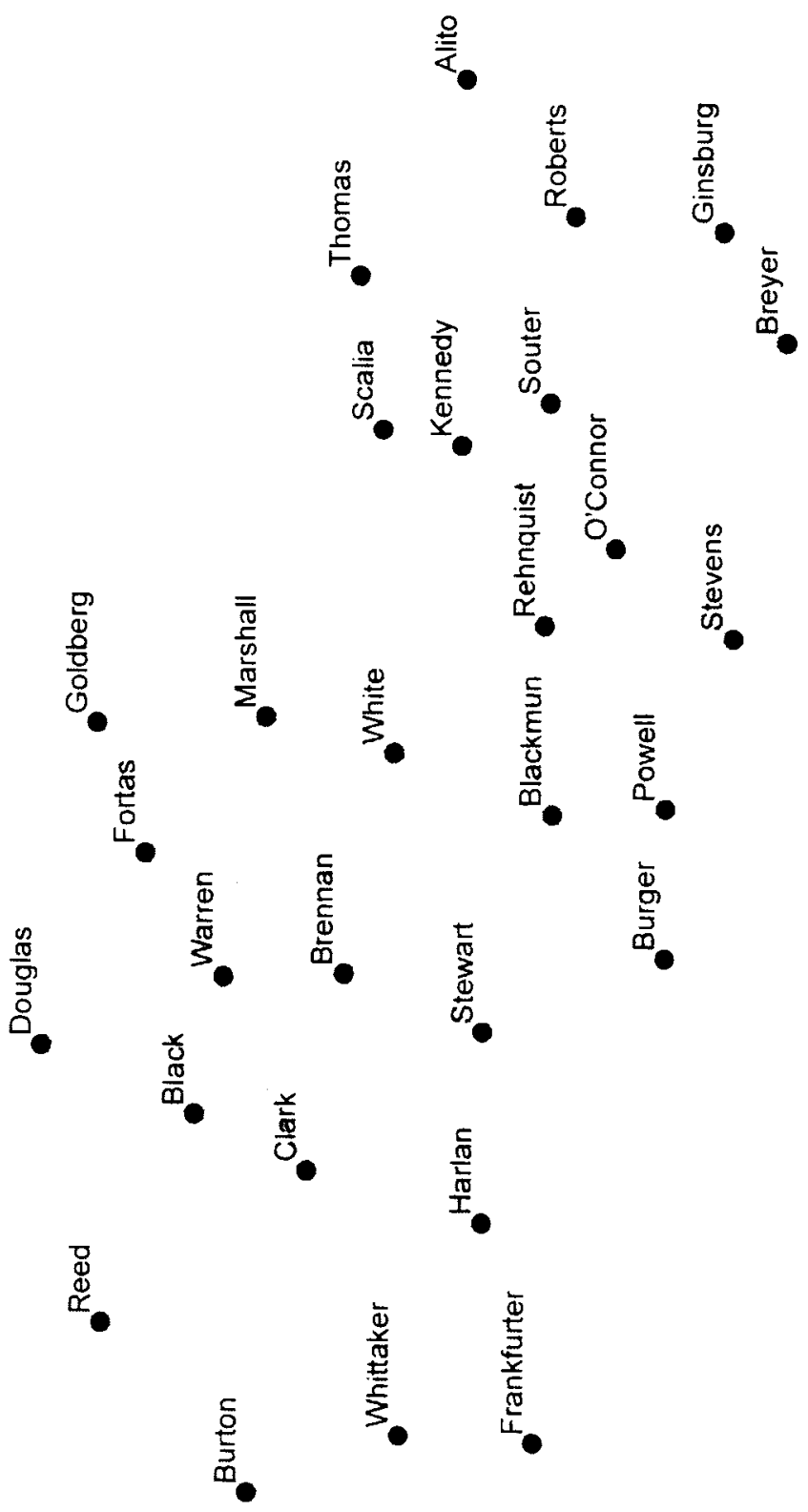


Chart 4 - Non-Unanimous Cases (1994-2003 Terms) (Spatial distribution based on co-voting using MDS and the software program R.) [Photos used by permission: Collection, The Supreme Court Historical Society.]
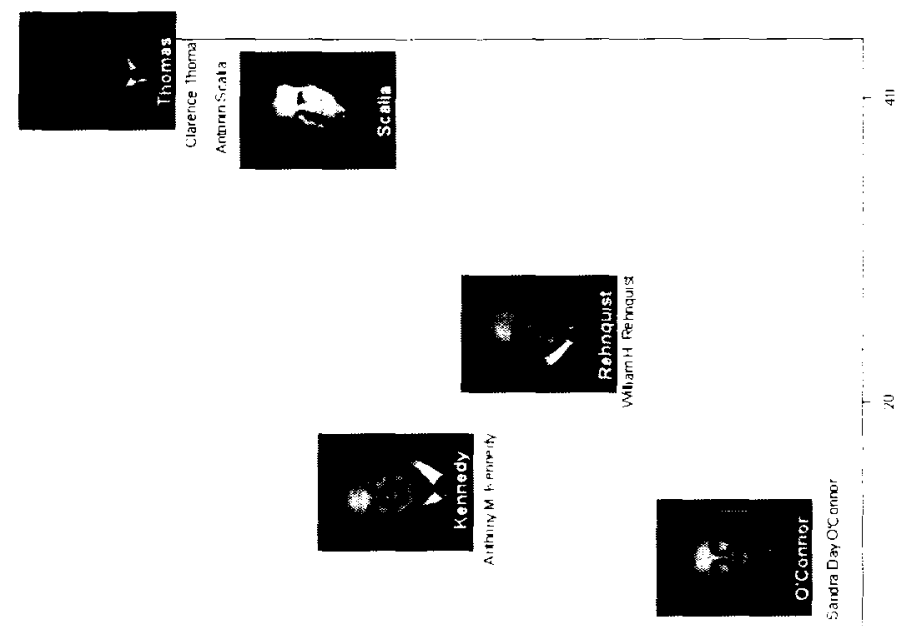

$\frac{5}{5}$
$\frac{0}{0}$
$\frac{2}{\mathbf{D}}$
$\stackrel{5}{0}$

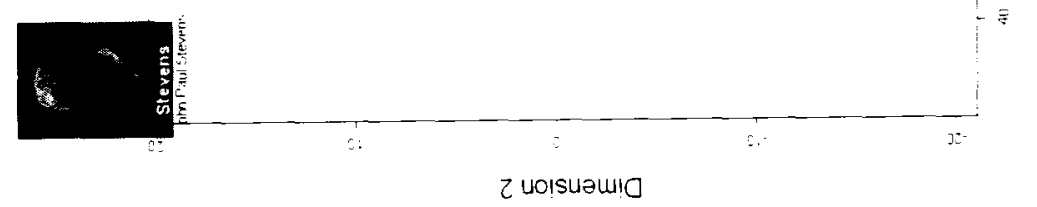


Chart 5 - Freedom of Speech Cases (1994-2003 Terms) (Spatial distribution based on co-voting using MDS and the software program R.) [Photos used by permission: Collection, The Supreme Court Historical Society.]

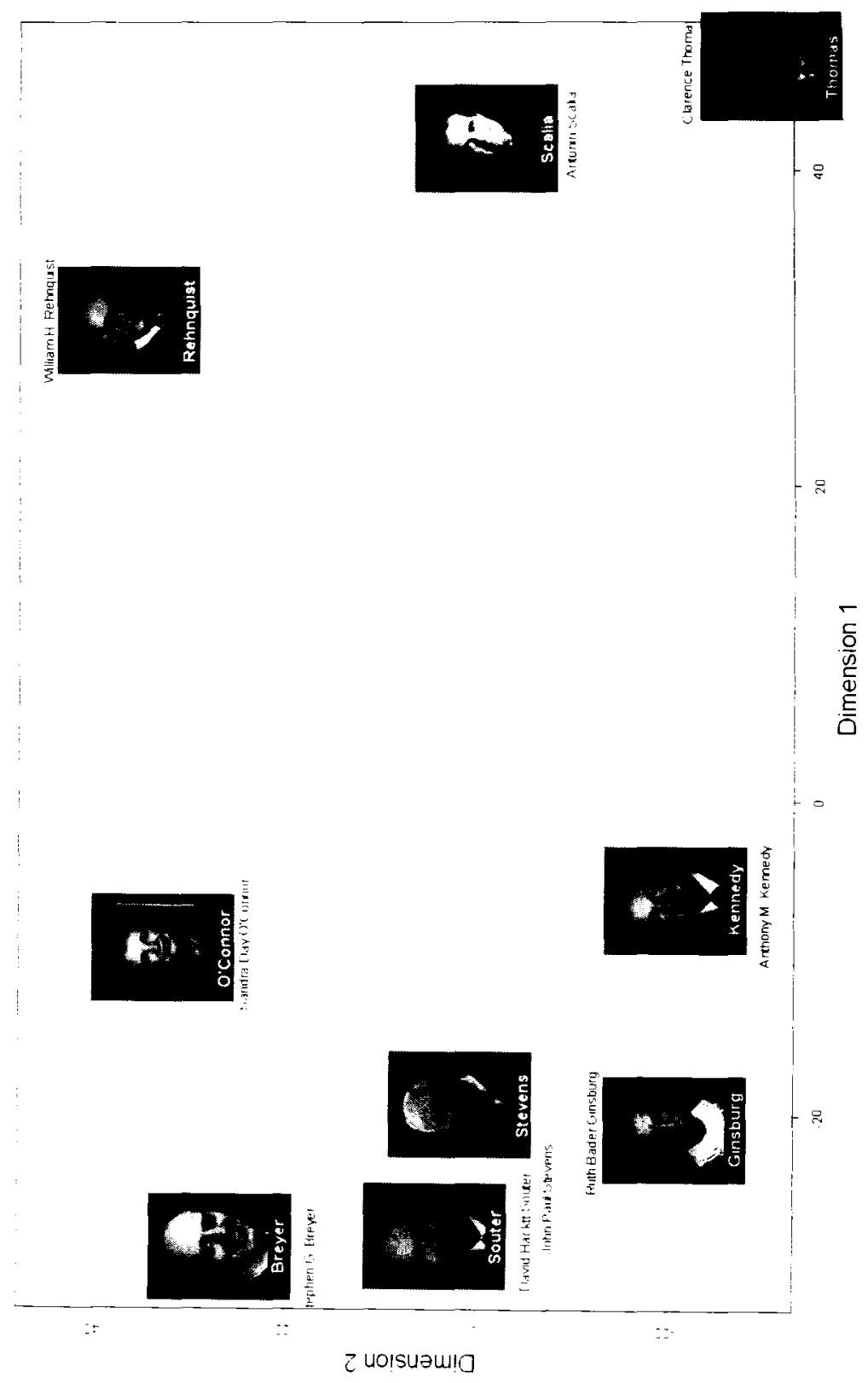


Chart 6 - Frequency of Voting Blocks in 5-4 Cases (1994-2003 Terms) [Photos used by permission: Collection, The Supreme Court Historical Society.]

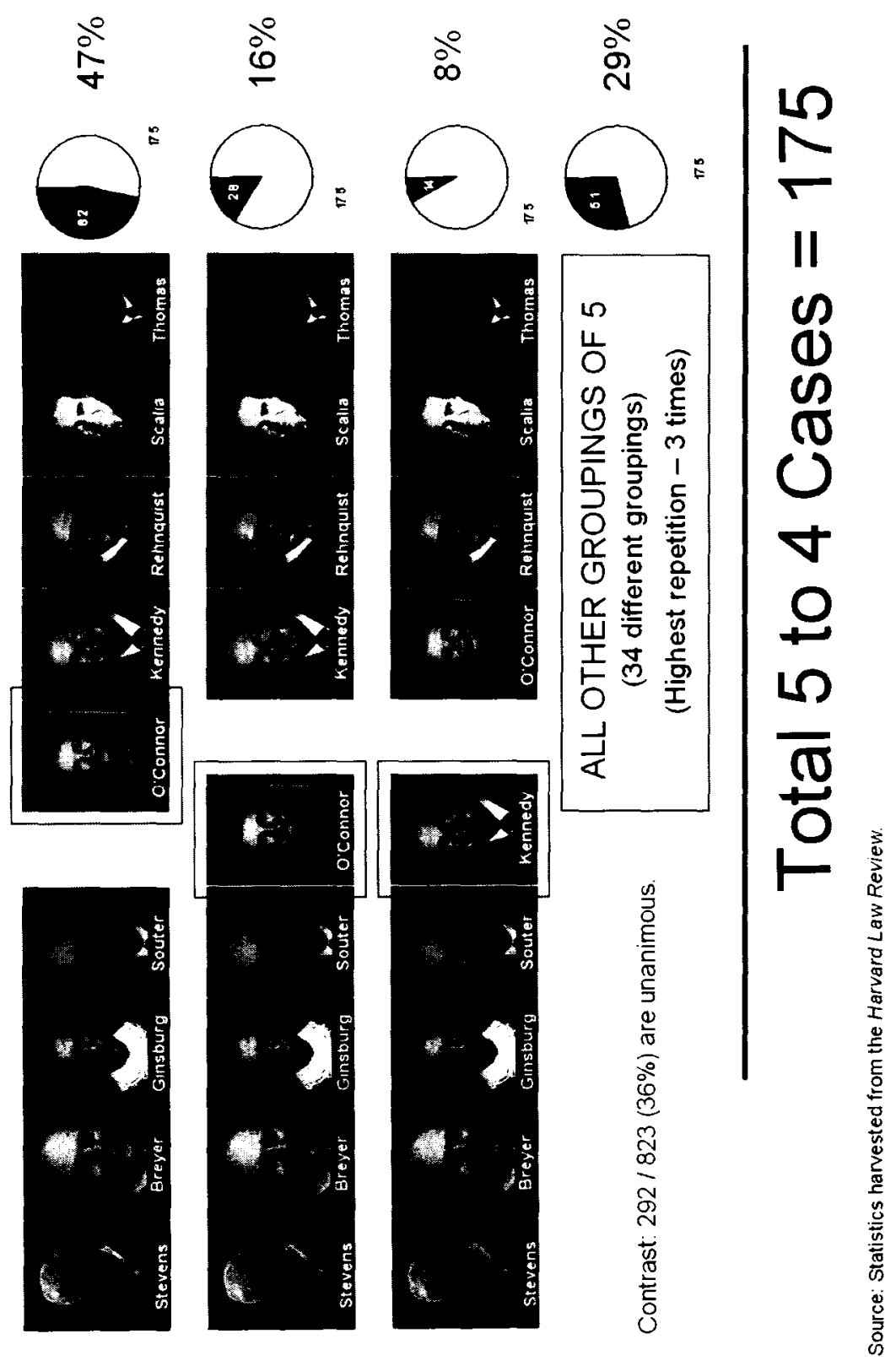


Chart 7 - Thresholding (Voting Together $>\mathbf{5 0} \%$ ) Reveals Ideological Cliques (1994-2003 Terms. Non-Unanimous Cases) [Photos used by permission: Collection, The Supreme Court Historical Society.] Voting frequencies represented as the edge weight between nodes and presented visually as a graph. (Rendered with Pajek using a stocahstic, spring force algorithm.)

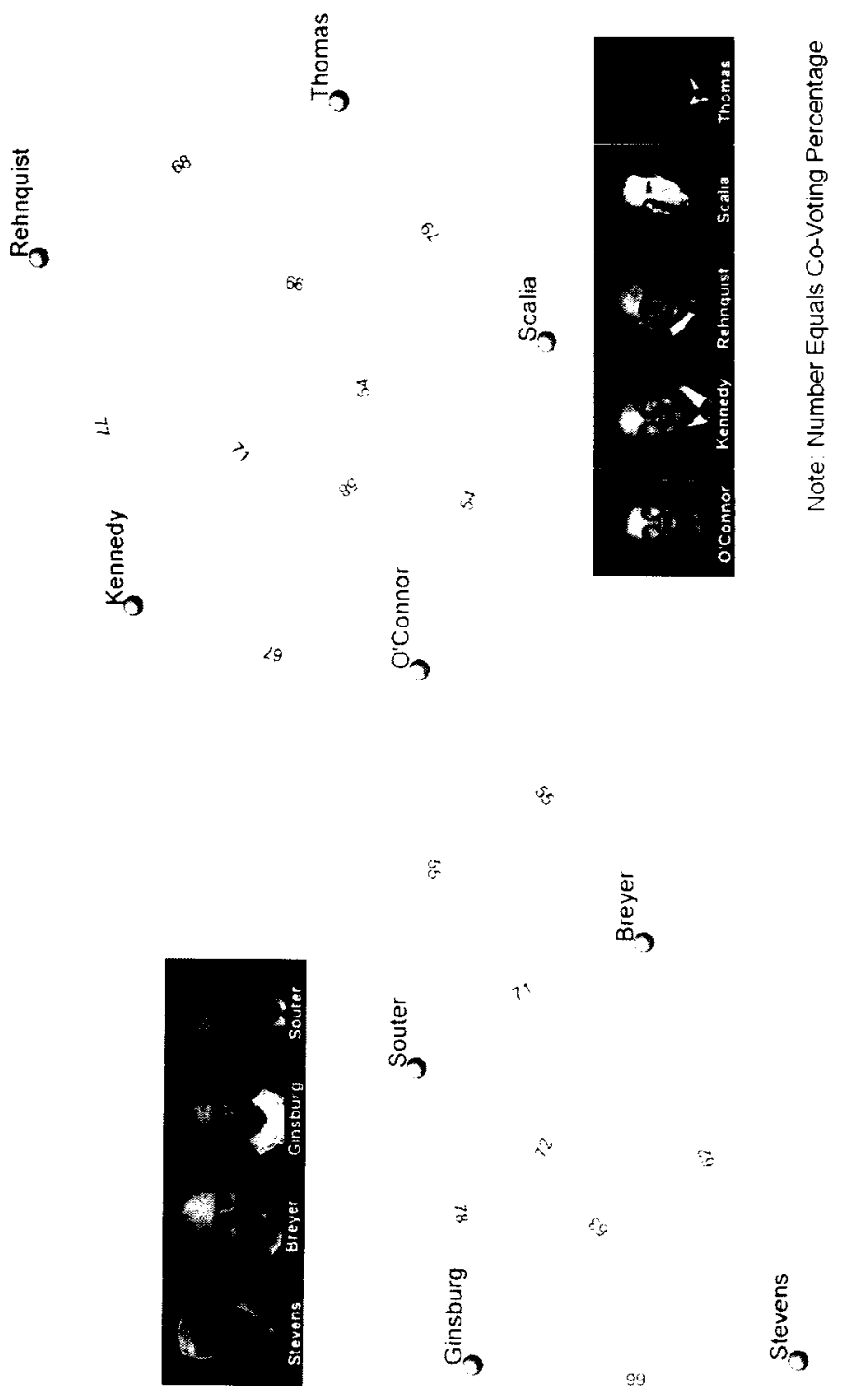


Chart 8 - Thresholding (Voting Together $>49 \%$ ) Reveals Ideological Cliques (1994-2003 Terms, Non-Unanimous Cases) [Photos used by permission: Collection, The Supreme Court Historical Society.] Voting frequencies represented as the edge weight between nodes and presented visually as a graph. (Rendered with Pajek using a stocahstic. spring force algorithm.)

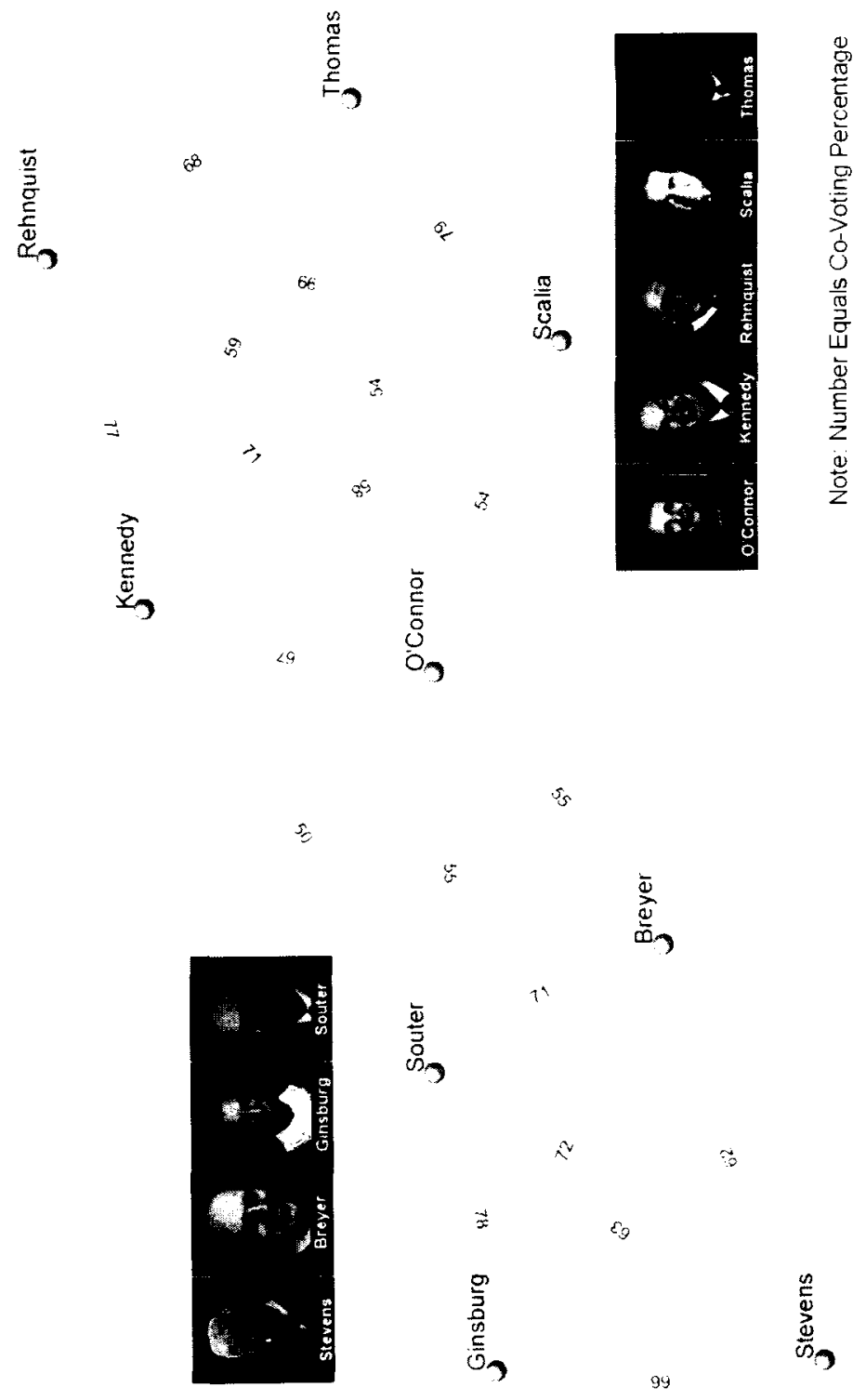


Table 6 - 25 Highest Co-Voting Percentages (1956-2005 Terms)

(Calculated from $\mathrm{O} \& \mathrm{~N}$ data from the Harvard Law Review)

\begin{tabular}{|c|c|c|c|c|}
\hline Rank & Justice 1 & Justice 2 & Percentage & $\begin{array}{c}\text { Number } \\
\text { of Cases } \\
\text { Heard } \\
\text { Together }\end{array}$ \\
\hline 1 & O'Connor & Roberts & 91 & 23 \\
\hline 2 & Warren & Marshall & 88 & 178 \\
\hline 3 & Reed & Clark & 85 & 40 \\
\hline 3 & Fortas & Marshall & 85 & 132 \\
\hline 5 & Warren & Brennan & 82 & 1406 \\
\hline 5 & Scalia & Roberts & 82 & 78 \\
\hline 5 & Roberts & Alito & 82 & 39 \\
\hline 8 & Warren & Fortas & 80 & 391 \\
\hline 9 & \begin{tabular}{|l|} 
Kennedy \\
\end{tabular} & Roberts & 79 & 78 \\
\hline 9 & Brennan & Fortas & 79 & 394 \\
\hline 11 & Thomas & Roberts & 78 & 77 \\
\hline 12 & Brennan & Goldberg & 77 & 308 \\
\hline 12 & \begin{tabular}{|l} 
Rehnquist \\
\end{tabular} & Kennedy & 77 & 1670 \\
\hline 14 & Burger & O'Connor & 76 & 790 \\
\hline 14 & Warren & Goldberg & 76 & 308 \\
\hline 16 & Warren & White & 75 & 770 \\
\hline 16 & O'Connor & Kennedy & 75 & 1685 \\
\hline 18 & Souter & Roberts & 74 & 78 \\
\hline 18 & Breyer & Roberts & 74 & 78 \\
\hline 18 & Powell & O'Connor & 74 & 888 \\
\hline 18 & Rehnquist & O'Connor & 74 & 2669 \\
\hline 18 & White & Kennedy & 74 & 688 \\
\hline 23 & \begin{tabular}{|l|} 
Ginsburg \\
\end{tabular} & Roberts & 73 & 78 \\
\hline 24 & Burger & Powell & 72 & 2070 \\
\hline 25 & Reed & Warren & 71 & 42 \\
\hline 25 & White & O'Connor & 71 & 1694 \\
\hline 25 & Clark & Brennan & 71 & 1169 \\
\hline 25 & Clark & White & 71 & 537 \\
\hline
\end{tabular}


Table 7 - 25 Highest Co-Voting Percentages of Justices Deciding 100 or More Cases Together (1956-2005 Terms) (Calculated from O \& N data from the Harvard Law Review)

\begin{tabular}{|c|c|c|c|c|}
\hline Rank & Justice 1 & Justice 2 & Percentage & $\begin{array}{c}\text { Number } \\
\text { of Cases } \\
\text { Heard } \\
\text { Together }\end{array}$ \\
\hline 1 & Warren & Marshall & 88 & 178 \\
\hline 2 & Fortas & Marshall & 85 & 132 \\
\hline 3 & Warren & Brennan & 82 & 1406 \\
\hline 4 & Warren & Fortas & 80 & 391 \\
\hline 5 & Brennan & Fortas & 79 & 394 \\
\hline 6 & Brennan & Goldberg & 77 & 308 \\
\hline 6 & Rehnquist & Kennedy & 77 & 1670 \\
\hline 8 & Burger & O'Connor & 76 & 790 \\
\hline 8 & Warren & Goldberg & 76 & 308 \\
\hline 10 & Warren & White & 75 & 770 \\
\hline 10 & O'Connor & Kennedy & 75 & 1685 \\
\hline 12 & Powell & O'Connor & 74 & 888 \\
\hline 12 & Rehnquist & O'Connor & 74 & 2669 \\
\hline 12 & White & Kennedy & 74 & 688 \\
\hline 15 & Burger & Powell & 72 & 2070 \\
\hline 16 & White & O'Connor & 71 & 1694 \\
\hline 16 & Clark & Brennan & 71 & 1169 \\
\hline 16 & Clark & White & 71 & 537 \\
\hline 19 & White & Souter & 70 & 335 \\
\hline 19 & Souter & Ginsburg & 70 & 1071 \\
\hline 19 & Burger & Rehnquist & 70 & 2166 \\
\hline 19 & Powell & Scalia & 70 & 147 \\
\hline 19 & White & Powell & 70 & 2215 \\
\hline 24 & O'Connor & Souter & 69 & 1337 \\
\hline 24 & Scalia & Kennedy & 69 & 1758 \\
\hline 24 & Souter & Breyer & 69 & 976 \\
\hline 24 & Rehnquist & Scalia & 69 & 1892 \\
\hline 24 & Rehnquist & Powell & 69 & 2200 \\
\hline 24 & White & Burger & 69 & 2464 \\
\hline 24 & Clark & Fortas & 69 & 195 \\
\hline 24 & Kennedy & Souter & 69 & 1404 \\
\hline
\end{tabular}


Table 8 - 25 Lowest Co-Voting Percentages (1956-2005 Terms)

(Calculated from $\mathrm{O} \& \mathrm{~N}$ data from the Harvard Law Review)

\begin{tabular}{|c|c|c|c|c|}
\hline Rank & Justice 1 & Justice 2 & Percentage & $\begin{array}{c}\text { Number } \\
\text { of Cases } \\
\text { Heard } \\
\text { Together }\end{array}$ \\
\hline 1 & Douglas & Rehnquist & 28 & 513 \\
\hline 2 & Douglas & Burger & 35 & 792 \\
\hline 3 & Douglas & Blackmun & 36 & 695 \\
\hline 4 & Douglas & Powell & 37 & 495 \\
\hline 5 & Frankfurter & Douglas & 38 & 588 \\
\hline 6 & Douglas & Harlan II & 39 & 1633 \\
\hline 7 & Marshall & Rehnquist & 41 & 2819 \\
\hline 7 & Douglas & Burton & 41 & 231 \\
\hline 7 & Black & Harlan II & 41 & 1628 \\
\hline 10 & Blackmun & Thomas & 42 & 284 \\
\hline 10 & Brennan & Rehnquist & 42 & 2706 \\
\hline 10 & Douglas & Whittaker & 42 & 523 \\
\hline 13 & Black & Frankfurter & 43 & 576 \\
\hline 13 & Marshall & Scalia & 43 & 685 \\
\hline 13 & Harlan II & Goldberg & 43 & 308 \\
\hline 16 & \begin{tabular}{|l|} 
Stevens \\
\end{tabular} & \begin{tabular}{|l} 
Thomas \\
\end{tabular} & 44 & 1266 \\
\hline 17 & Stevens & Alito & 45 & 40 \\
\hline 17 & Black & Burton & 45 & 222 \\
\hline 19 & Douglas & Stewart & 46 & 1963 \\
\hline 19 & Frankfurter & Warren & 46 & 587 \\
\hline 19 & Brennan & Scalia & 46 & 565 \\
\hline 19 & Stevens & Scalia & 46 & 1978 \\
\hline 19 & Marshall & Burger & 46 & 2424 \\
\hline 24 & Black & Whittaker & 47 & 515 \\
\hline 24 & Brennan & Burger & 47 & 2440 \\
\hline 24 & Marshall & O'Connor & 47 & 1462 \\
\hline
\end{tabular}


Table 9 - 25 Most Cases Heard Together (1956-2005 Terms)

(Calculated from the $\mathrm{N}$ data from the Harvard Law Review)

\begin{tabular}{|l|l|l|c|c|}
\hline Rank & Justice 1 & Justice 2 & $\begin{array}{c}\text { Co-Voting } \\
\text { Percentage }\end{array}$ & $\begin{array}{c}\text { Number } \\
\text { of Cases } \\
\text { Heard } \\
\text { Together }\end{array}$ \\
\hline 1 & Brennan & White & 59 & 3786 \\
\hline 2 & Rehnquist & Stevens & 51 & 3432 \\
\hline 3 & White & Marshall & 54 & 3285 \\
\hline 4 & White & Blackmun & 64 & 3257 \\
\hline 5 & Brennan & Marshall & 61 & 3140 \\
\hline 6 & Blackmun & Rehnquist & 58 & 3137 \\
\hline 7 & White & Rehnquist & 68 & 3078 \\
\hline 8 & Marshall & Blackmun & 53 & 3005 \\
\hline 9 & Brennan & Blackmun & 54 & 2884 \\
\hline 10 & Marshall & Rehnquist & 41 & 2819 \\
\hline 11 & Brennan & Stewart & 57 & 2812 \\
\hline 12 & Brennan & Rehnquist & 42 & 2706 \\
\hline 13 & Stevens & O'Connor & 55 & 2696 \\
\hline 14 & Rehnquist & O'Connor & 74 & 2669 \\
\hline 15 & Blackmun & Stevens & 54 & 2536 \\
\hline 16 & White & Stevens & 56 & 2472 \\
\hline 17 & White & Burger & 69 & 2464 \\
\hline 18 & Brennan & Burger & 47 & 2440 \\
\hline 19 & Stewart & White & 62 & 2428 \\
\hline 20 & Marshall & Burger & 46 & 2424 \\
\hline 21 & Burger & Blackmun & 66 & 2349 \\
\hline 22 & Marshall & Stevens & 50 & 2219 \\
\hline 23 & White & Powell & 70 & 2215 \\
\hline 24 & Douglas & Brennan & 60 & 2213 \\
\hline 25 & Rehnquist & Powell & 69 & 2200 \\
\hline & & & \\
\hline
\end{tabular}


Table 10 - Statistics About the 193 Justice Pairings over the 50 Years of the Dataset (1956-2005 Terms)

\begin{tabular}{|l|c|}
\hline Total Number of Possible Justice Pairings & 193 \\
\hline Range Of Co-Voting Percentages & $28 \%$ to $91 \%$ \\
\hline Mean of Co-Voting Percentages & $59.93 \%$ \\
\hline Median of Co-Voting Percentages & $60 \%$ \\
\hline Mode of Co-Voting Percentages & $58 \%$ \\
\hline $1^{\text {st }}$ Quartile & $0 \%$ to $53 \%$ \\
\hline $2^{\text {nd }}$ Quartile & $53.01 \%$ to $59.93 \%$ \\
\hline $3^{\text {rd }}$ Quartile & $59.94 \%$ to $68 \%$ \\
\hline $4^{\text {th }}$ Quartile & $68.01 \%$ to $100 \%$ \\
\hline
\end{tabular}


Chart 9

Histogram of Percentages of Co-Voting, $O$ Method

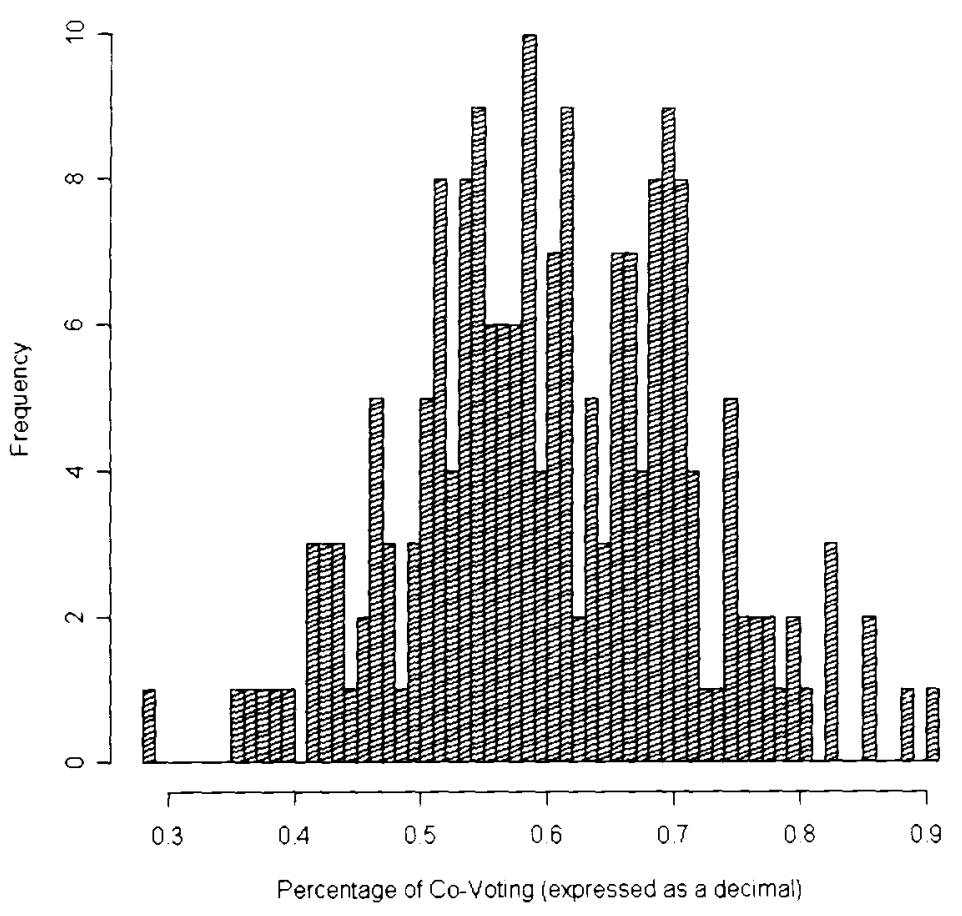

